\title{
Fire severity, time since fire, and site-level characteristics influence streamwater chemistry at baseflow conditions in catchments of the Sierra Nevada, California, USA
}

Fernanda Santos ${ }^{1 *}$ (D), Adam S. Wymore ${ }^{2}$, Breeanne K. Jackson³,4, S. Mažeika P. Sullivan ${ }^{4}$, William H. McDowell ${ }^{2}$ and Asmeret Asefaw Berhe ${ }^{1}$

\begin{abstract}
Background: Fire plays an important role in controlling the cycling and composition of organic matter and nutrients in terrestrial and aquatic ecosystems. In this study, we investigated the effects of wildfire severity, time since fire, and site-level characteristics on (1) concentration of multiple solutes (dissolved organic carbon, DOC; total dissolved nitrogen, TDN; dissolved organic nitrogen, DON; calcium, $\mathrm{Ca}^{2+}$; magnesium, $\mathrm{Mg}^{2+}$; potassium, $\mathrm{K}^{+}$; sodium, $\mathrm{Na}^{+}$; chloride, $\mathrm{Cl}^{-}$; nitrate, $\mathrm{NO}_{3}{ }^{-}$; ammonium, $\mathrm{NH}_{4}{ }^{+}$; sulfate, $\mathrm{SO}_{4}{ }^{2-}$; and phosphate, $\mathrm{PO}_{4}{ }^{3-}$ ), and (2) the molecular composition of stream-dissolved organic matter (DOM) across 12 streams sampled under baseflow conditions in Yosemite National Park, California, USA. Samples were collected from low- and high-severity burned stream reaches, as well as an unburned reference stream reach.
\end{abstract}

Results: Fire severity, time since fire, and variability in site-level characteristics emerged as the strongest influences on streamwater chemistry. Results from mixed-effect models indicated that DOC and DON concentrations decreased with time since fire in high-severity burned stream reaches. In low-severity burned stream reaches, DOC concentrations increased, and DON concentrations slightly decreased with time since fire. We also found that declines in aromaticity (expressed as decreased SUVA 254 ) and mean molecular weight DOM (expressed as increased $\mathrm{E}_{2} \mathrm{E}_{3}$ ratios) with time since fire were associated with high-severity fires. Mixed-effect models also indicated that site-level characteristics played a role in solute responses. Aliphatic structures dominated streamwater DOM composition across fire-impacted catchments, but neither fire severity nor time since fire was a significant predictor of the proportion of aliphatic structures in streamwater DOM. North aspect exhibited the highest concentrations of $\mathrm{Ca}^{2+}, \mathrm{K}^{+}$, and $\mathrm{Mg}^{2+}$, whereas the north-northwest aspect exhibited the highest concentrations of $\mathrm{Cl}^{-}$and $\mathrm{SO}_{4}{ }^{2+}$. We also observed elevated $\mathrm{Ca}^{2+}, \mathrm{K}^{+}$, and $\mathrm{Mg}^{2+}$ in burned (but not reference) stream reaches with pool-riffle versus step-pool bed morphology.

Conclusions: Taken together, our findings suggest that the response of stream chemistry to wildfires in the Sierra Nevada, California, can persist for years, varying with both fire severity and site-specific characteristics. These impacts may have important implications for biogeochemical cycles and productivity in aquatic ecosystems in fire-adapted landscapes.

Keywords: ${ }^{1} \mathrm{H}-\mathrm{NMR}$, aromaticity, catchment, dissolved organic carbon, fire severity, Sierra Nevada, solute chemistry, streamwater, time since fire, wildfire

\footnotetext{
* Correspondence: fsantos4@ucmerced.edu

'School of Natural Sciences, Department of Life and Environmental Sciences,

University of California, 5200 North Lake Road, Merced, CA 95343, USA

Full list of author information is available at the end of the article
} 


\section{Resumen}

Antecedentes: El fuego juega un rol importante en el control del ciclado y composición de la materia orgánica y los nutrientes en ecosistemas terrestres y acuáticos. En este estudio, investigamos los efectos de la severidad del fuego, el tiempo desde el incendio, y las características a nivel de sitio sobre (1) la concentración de múltiples solutos (carbono orgánico disuelto, DOC; nitrógeno total disuelto, TND; nitrógeno orgánico disuelto, DON; calcio, $\mathrm{Ca}^{2+}$; magnesio, $\mathrm{Mg}^{2+}$; potasio, $\mathrm{K}^{+}$; sodio, $\mathrm{Na}^{+}$; cloro, $\mathrm{Cl}^{-}$; nitratos, $\mathrm{NO}_{3}{ }^{-}$; amonio, $\mathrm{NH}_{4}{ }^{+}$; sulfate, $\mathrm{SO}_{4}{ }^{2-}$; y fosfato, $\mathrm{PO}_{4}{ }^{3-}$ ), y (2) la composición molecular de la materia orgánica disuelta en cursos de agua (DOM) en 12 arroyos de estío muestreados en el Parque Nacional Yosemite, California, EEUU. Las muestras fueron colectadas en secciones de los arroyos que presentaban condiciones de quemado de baja a alta severidad como así también una sección no quemada y usada como referencia o control.

Resultados: La severidad del fuego, el tiempo desde la ocurrencia del incendio, y la variabilidad en las características a nivel de sitio emergieron como las influencias más fuertes en la química del agua de estos arroyos. Los resultados de los efectos de modelos mixtos indicaron que las concentraciones de DOC and DON decrecieron en el tiempo desde el inicio del incendio en las secciones de los arroyos que habían tenido fuegos de alta severidad. En aquellas secciones de los arroyos que habían tenido incendios de baja severidad, las concentraciones de DOC se incrementaron y las de DON decrecieron levemente en el tiempo desde el incendio. Encontramos asimismo decrementos en aromaticidad (expresado como decrecimiento de SUVA ${ }_{254}$ ) y en el peso molecular medio de DON (expresado como un incremento de la relación $\mathrm{E}_{2}: \mathrm{E}_{3}$ ) en el tiempo desde el inicio del fuego en incendios de alta severidad. Los Modelos de Efectos Mixtos también indicaron que las características a nivel de sitio tuvieron un rol importante en la respuesta de los solutos. Las estructuras alifáticas dominaron la composición de DOM en el agua de los arroyos a través de las microcuencas impactadas por el fuego, pero ni la severidad del fuego ni el tiempo desde el incendio fueron predictores importantes de la proporción de estructuras alifáticas DOM en el agua de estos arroyos. La exposición norte exhibió las concentraciones más altas de $\mathrm{Ca}^{2+}, \mathrm{K}^{+}, \mathrm{y} \mathrm{Mg}^{2+}$, mientras que las ubicadas en exposiciones nornoroeste exhibieron las concentraciones más altas de $\mathrm{Cl}^{-}$y $\mathrm{SO}_{4}{ }^{2+}$. Observamos asimismo elevadas concentraciones de $\mathrm{Ca}^{2+}, \mathrm{K}^{+}, \mathrm{y} \mathrm{Mg}^{2+}$ (aunque no como referencia) en secciones de arroyo quemadas y que responden al tipo remanso o palangana versus aquellas en las cuales las secciones se presentan en sitios más profundos y estrechos del tipo rápidos.

Conclusiones: Tomados en conjunto, nuestros resultados sugieren que la respuesta química de los arroyos a los incendios en la Sierra Nevada, California, pueden persistir por años, variando de acuerdo a la severidad del fuego y a las características específicas de cada sitio. Estos impactos pueden tener implicancias importantes para los ciclos biogeoquímicos y la productividad en ecosistemas acuáticos de paisajes adaptados al fuego.

\section{Introduction}

Wildfire plays a pivotal role in controlling the dynamics of organic matter $(\mathrm{OM})$ and inorganic solutes in both terrestrial and aquatic ecosystems. Fire can alter hydrologic flow paths in soil and increases susceptibility of soils to erosion (Spigel and Robichaud 2007, Florsheim et al. 2017). These changes increase the rate at which sediments, dissolved and particulate carbon $(C)$, and nutrients are transported from post-fire landscapes and delivered to fluvial networks (Moody et al. 2013, Dahm et al. 2015, Mast et al. 2016, Abney et al. 2017, Esposito et al. 2017). For example, post-fire erosion mobilized 19.8 to 33.1 tons $\mathrm{ha}^{-1}$ of soil from a mountainous fire-impacted catchment in Italy (Esposito et al. 2017), and total dissolved solids and nitrate $\left(\mathrm{NO}_{3}{ }^{-}\right)$were reported to increase 20 and 52\%, respectively, in a Colorado Front Range river two years following fire (Mast et al. 2016). However, there are limited data available on how fire characteristics, including factors such as time since fire and fire severity (Keeley 2009), affect streamwater chemistry.

Fires can alter the cycling, concentration, and chemical composition of OM in soil (Santín et al. 2015, Araya et al. 2016, Santos et al. 2016, Araya et al. 2017) and aquatic ecosystems (Jaffé et al. 2013, Masiello and Louchouarn 2013). The thermal degradation of soil organic $\mathrm{C}$ and biomass produces a heterogeneous mixture of organic residues that are collectively referred to as pyrogenic (fire-derived) $\mathrm{C}$ (PyC). In post-fire landscapes, large quantities of $\mathrm{PyC}$ (as determined by an increase in degree of aromaticity) can be mobilized and transported to fluvial systems as particulate and dissolved $C$ (particle size $<0.7 \mu \mathrm{m}$; Güereña et al. 2015, Myers-Pigg et al. 2015, Wagner et al. 2015, Cotrufo et al. 2016, Abney et al. 2017, Abney and Berhe 2018). Global estimates indicate that at least $10 \%$ of the dissolved organic carbon (DOC) pool transported in rivers is in the form of $\mathrm{PyC}$ (Dittmar et al. 2012, Jaffé et al. 2013); however, the 
response of DOC to fire occurrence is highly variable with concentrations increasing (Ramchunder et al. 2013), decreasing (Betts and Jones 2009, Parham et al. 2013, Diemer et al. 2015), and showing no significant response (Mast and Clow 2008, Mast et al. 2016).

Spatial and temporal variability in the response of dissolved organic matter (DOM) indicates that the export of $\mathrm{PyC}$ to streams and rivers is likely driven by multiple factors including, for example, fuel accumulation, fire severity, hydrologic flowpaths, soil type, geomorphology of the landscape (i.e., slope steepness and length, curvature, and aspect), and time since fire (Parham et al. 2013, Larouche et al. 2015, Abney et al. 2017). In contrast, elevated solute concentrations in streams are often reported in post-fire landscapes (Chorover et al. 1994, Williams and Melack 1997; Smith et al. 2011, Parham et al. 2013). For example, nitrate anion $\left(\mathrm{NO}_{3}{ }^{-}\right)$and cation (calcium, $\mathrm{Ca}^{2+}$; magnesium, $\mathrm{Mg}^{2+}$; and potassium, $\mathrm{K}^{+}$) concentrations often remain elevated for $>2 \mathrm{yr}$ following fire (Chorover et al. 1994, Mast and Clow 2008, Rhoades et al. 2011). However, less is known about how the concentrations of major solutes in streams respond to different levels of disturbances related to fire severity (i.e., low- versus high-severity fire), and site-level characteristics such as catchment area, vegetation cover, and stream geomorphology. This is especially critical in the western US. where the proportion of large patches affected by high-severity fire is increasing (Miller et al. 2009, Miller and Safford 2012, Reilly et al. 2017). As a result, the ability to produce a robust, predictive framework for the responses of streamwater chemistry to wildfire remains elusive.

The objective of this study was to examine the potential influences of fire severity and time since last fire on streamwater chemistry by examining solute concentrations and DOM composition. We hypothesized that nutrient, cation, and anion concentrations would be positively correlated with high-severity fire ( $>1 \mathrm{yr}$ following wildfire), whereas DOC concentration would be negatively correlated with high-severity fires. We also expected to see an increase in aromaticity and a decrease in molecular weight (MW) of DOM corresponding with high-severity fire, as an increase in fire severity would lead to higher proportions of PyC (Knicker 2007) and low molecular weight DOM (Norwood et al. 2013, Santos et al. 2016) transported from soils to streams. Additionally, we hypothesized that streamwater solute concentrations would decrease with an increase in time since fire due to ecosystem recovery; whereas aromaticity would increase with time since fire as soil $\mathrm{PyC}$ would become progressively more oxidized and hydrophilic, therefore highly mobile, over time (Knicker 2007, Abiven et al. 2011, Näthe et al. 2017). To test these hypotheses, we measured nutrient, cation and anion, and
DOC concentrations, MW of DOM, as well as the distribution of major chemical functional groups in streamwater DOM across sites that differed in time since fire (from 1 to $13 \mathrm{yr}$ since last burn) and experienced either low- or high-severity wildfires in the Sierra Nevada of California, USA.

\section{Materials and methods}

\section{Sites}

Streams selected for this study were located in Yosemite National Park, in the Sierra Nevada, California, USA, and were tributaries of the Tuolumne and Merced rivers. This study consisted of six low-severity and six high-severity burned sites or reaches (each within its own catchment or sub-catchment), with burn severity assessed at the reach scale (Jackson and Sullivan 2015), as shown in Table 1 and Fig. 1. The dominant upland vegetation types were: California Red Fir Belt in Tamarack, Frog, Cascade, Crane, Chilnualna, and Coyote creeks; Mixed Conifer in Grouse, Middle Tuolumne, and South Tuolumne creeks; Subalpine Conifer in Meadow, Camp, Buena Vista, and Mono creeks (Keeler-Wolf et al. 2012). Chaparral was also commonly interspersed within coniferous vegetation zones (Keeler-Wolf et al. 2012). Ponderosa pine (Pinus ponderosa Douglas ex C. Lawson), Jeffrey pine (Pinus jeffreyi Balf.), sugar pine (Pinus lambertiana Douglas), red fir (Abies magnifica A. Murray bis), lodgepole pine (Pinus contorta Douglas ex Loudon var. murrayana [Balf.] Englem.), incense-cedar (Libocedrus decurrens [Torr.] Florin), chinquapin (Castanopsis sempervirens [Kellogg] Dudley), and buck brush (Ceanothus L. spp.) were among the dominant upland species observed in the riparian zone (Sawyer et al. 2009, Keeler-Wolf et al. 2012). Riparian species included quaking aspen (Populus tremuloides Michx.), mountain azalea (Rhododendron occidentale Torr. \& A. Gray), red-osier dogwood (Cornus sericea L. ssp. occidentalis [Torr. \& A. Gray] Fosberg), and willow (Salix L. spp.) (Sawyer et al. 2009).

Elevation of the study sections varied between 1574 and $2154 \mathrm{~m}$ a.s.l., with time since fire ranging from 1 to $13 \mathrm{yr}$ (see Table 1 for other site-level characteristics); all fires were naturally occurring wildfires (not prescribed). Our main goal was to examine the effect of fire severity (low versus high), but we also sampled an unburned reference stream (Chilnualna Creek), which served as a counterpoint to our burned streams, and helped us to identify changes in streamwater chemistry attributable to fire. Middle Tuolumne and South Tuolumne study reaches were within the perimeter of the Rim Fire, a high-severity fire that started in August 2013, burning an area of approximately $1041 \mathrm{~km}^{2}$ (Lydersen et al. 2014). The Rim Fire was considered the largest wildfire in recorded Sierra Nevada history to date. 
Table 1 Fire and site-level characteristics for study reaches in Yosemite National Park, California, USA (modified from Jackson and Sullivan 2015). Channel-reach morphology was classified following Montgomery and Buffington (1997). Stream order was determined based on Strahler (1957). Aspect was used as a coarse proxy for heat load (McCune and Keon 2002). Streamwater was sampled from the sites between 1 and 13 years after the last fire

\begin{tabular}{|c|c|c|c|c|c|c|c|c|}
\hline Streams & $\begin{array}{l}\text { Catchment } \\
\text { size }\left(\mathrm{km}^{2}\right)\end{array}$ & $\begin{array}{l}\text { Burn } \\
\text { severity }\end{array}$ & $\begin{array}{l}\text { Time since } \\
\text { fire (years) }\end{array}$ & Elevation (m) & Aspect & $\begin{array}{l}\text { Stream } \\
\text { order }\end{array}$ & $\begin{array}{c}\text { Channel-reach } \\
\text { morphology }\end{array}$ & Dominant riparian vegetation \\
\hline Chilnualna & 18.8 & Reference & $>100$ & 2008 & W & 3 & Pool-riffle & Salix, Cornus L., Rhododendron L. \\
\hline South Tuolumne & 34.8 & Low & 1 & 1716 & NW & 3 & Step-pool & Salix, Alnus (Torr. \& A. Gray) A. Gray \\
\hline Grouse & 10.1 & Low & 5 & 1574 & NW & 3 & Step-pool & Alnus, Cornus \\
\hline Coyote & 4.9 & Low & 7 & 1836 & SE & 2 & Step-pool & Salix, Cornus, Rhododendron \\
\hline Cascade & 26.9 & Low & 7 & 1864 & SW & 3 & Step-pool & Salix, Cornus, Rhododendron \\
\hline Camp & 1.4 & Low & 9 & 2098 & $\mathrm{~N}$ & 1 & Pool-riffle & Alnus, Cornus \\
\hline Mono & 20.8 & Low & 10 & 2096 & $\mathrm{~N}$ & 3 & Pool-riffle & Salix, Cornus, Alnus \\
\hline Middle Tuolumne & 94.3 & High & 1 & 1766 & SW & 3 & Pool-riffle & Salix, Populus L., Rhododendron \\
\hline Tamarack & 10.6 & High & 5 & 1931 & S & 2 & Step-pool & Salix \\
\hline Crane & 6.5 & High & 5 & 1850 & E & 2 & Step-pool & Cornus, Rhododendron \\
\hline Frog & 43.9 & High & 8 & 1909 & S & 3 & Step-pool & Salix, Cornus, Rhododendron \\
\hline Meadow & 2.0 & High & 9 & 2127 & N & 1 & Pool-riffle & Salix \\
\hline Buena Vista & 35.2 & High & 13 & 2154 & NNW & 3 & Step-pool & Salix, Rubus L., Alnus \\
\hline
\end{tabular}

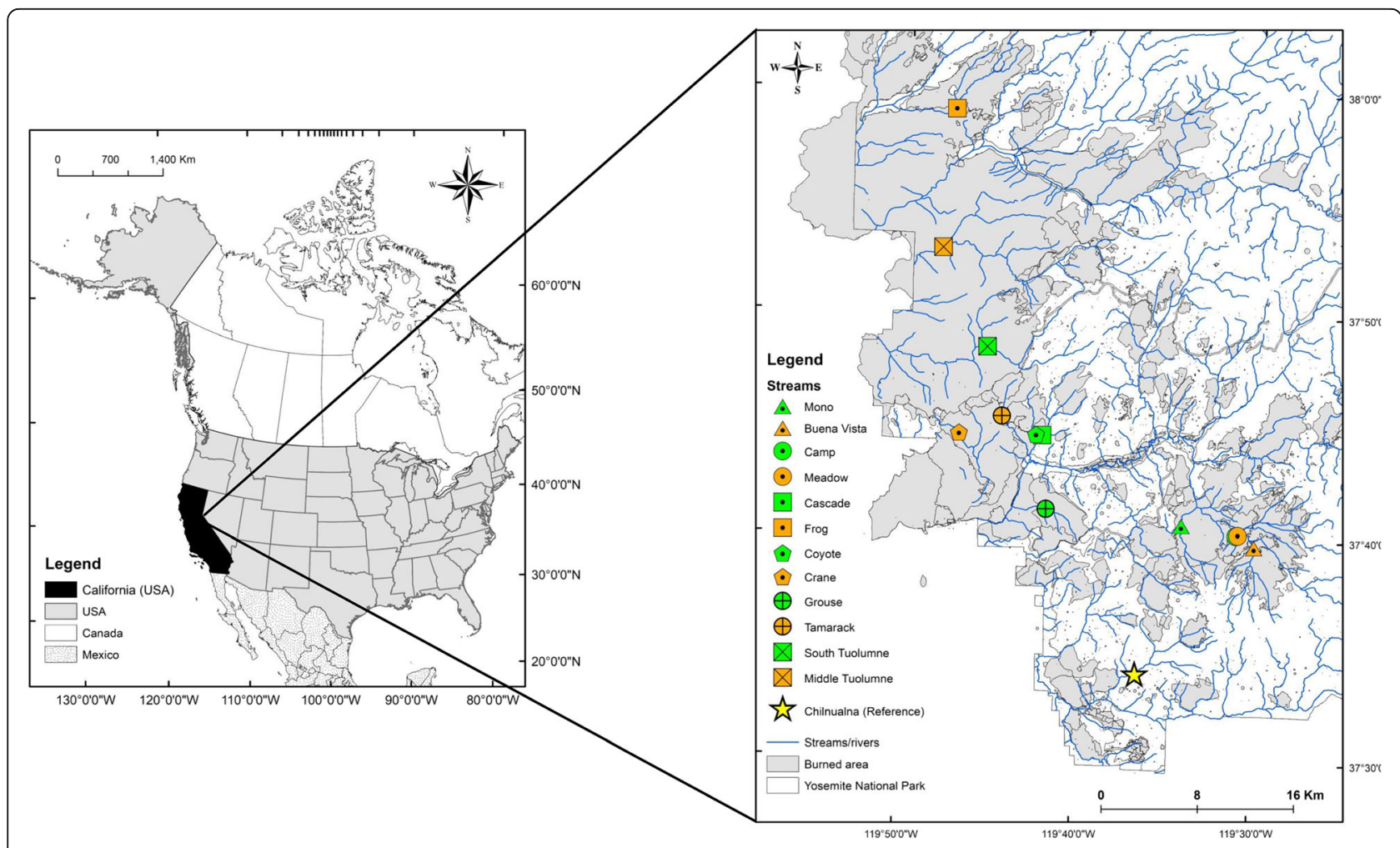

Fig. 1 Sampling locations in sites affected by low-severity (green) and high-severity (orange) fire in Yosemite National Park in the Sierra Nevada, California, USA. Streamwater was sampled from the sites between 1 and 13 years after the last fire 
Fire severity at each study reach was determined based on the condition of the conifer canopy within approximately $50 \mathrm{~m}$ of the stream (i.e., those trees that could influence light penetration into the stream). Low-severity reaches were characterized as having an intact conifer canopy, despite the riparian understory having burned. High-severity reaches were characterized as having its conifer canopy removed by wildfire over at least $75 \%$ of the reach (Jackson and Sullivan 2009, Malison and Baxter 2010).

\section{Sample collection and solute analysis}

We collected streamwater samples every two weeks from June through October 2014 (reference, $n=8$; low-severity, $n=48$; high-severity, $n=46$ ). All sampling occurred between 10 and 14 months after the Rim Fire started. Samples were collected at baseflow, during daylight hours, and from the middle of the channel (i.e., laterally) and stream reach (i.e., longitudinally). Samples were filtered through Whatman GF/F filters (GE Healthcare Bio-Sciences, Pittsburgh, Pennsylvania, USA) and into acid-washed $125 \mathrm{ml}$ HDPE bottles, and were immediately placed on ice, and frozen upon return to the laboratory. Samples were sent overnight to the University of New Hampshire's Water Quality Analysis lab.

We analyzed DOC and total dissolved nitrogen (TDN) using high temperature catalytic oxidation on a Shimadzu TOC-VSCH with TNM-1 nitrogen unit (Shimadzu, Marlboro, Massachusetts, USA). Cations and anions were measured using ion chromatography with a Dionex ICS-1000 (ICS 1000; Dionex, Sunnyvale, California, USA), and ammonium cations $\left(\mathrm{NH}_{4}{ }^{+}\right)$with a SmartChem 200 discrete automated colorimetric analyzer (Westco, Brookfield, Connecticut, USA) using the alkaline phenate standard method (EPA method 350.1; US EPA 1993). Dissolved organic nitrogen (DON) was calculated as the difference between TDN and dissolved inorganic nitrogen $\left(\mathrm{NO}_{3}{ }^{-}+\mathrm{NH}_{4}{ }^{+}\right)$. Values below instrument specific minimum detection limit (MDL) were replaced with half the MDL.

\section{Specific ultraviolet-visible (UV) absorbance}

Specific UV absorbance at $254 \mathrm{~nm}\left(\mathrm{SUVA}_{254}\right)$ was used as a proxy for aromaticity in DOC (Weishaar et al. 2003) on samples collected from August through October (reference, $n=4$; low-severity, $n=29$; high-severity, $n=28$ ). We measured absorbance between 200 and $400 \mathrm{~nm}$ using a UV-VIS spectrophotometer (Evolution 300; Thermo Scientific, Waltham, Massachusetts, USA). Samples were analyzed inside a quartz cell with $1.0 \mathrm{~cm}$ path length, and we calculated $\mathrm{SUVA}_{254}\left(\mathrm{mg} \mathrm{C} \mathrm{L}^{-1} \mathrm{~m}^{-1}\right)$ by dividing the specific absorbance coefficient at $254 \mathrm{~nm}$ by the path length $(\mathrm{m})$ and DOC concentration ( $\mathrm{mg} \mathrm{C} \mathrm{L}^{-1}$ ), as described by Weishaar et al. (2003). We used ultrapure water as the blank. As high-molecularweight molecules are expected to absorb light more strongly at longer wavelengths than at shorter wavelengths, we also used the ratio of absorption coefficients at $250 \mathrm{~nm}$ to $365 \mathrm{~nm}\left(\mathrm{E}_{2}: \mathrm{E}_{3}\right)$ to infer molecular size of organic compounds in DOM (Helms et al. 2008). The ratio $\mathrm{E}_{2}: \mathrm{E}_{3}$ is inversely correlated with the molecular size of DOM compounds.

\section{Solution-state ${ }^{1} \mathrm{H}$-NMR spectroscopy}

The composition of streamwater DOM was only determined on filtered samples collected from August through October (reference, $n=4$; low-severity, $n=29$; high-severity, $n=28)$ using liquid-state 1 -D ${ }^{1} \mathrm{H}-\mathrm{NMR}$ spectroscopy (described below), which provides information on the molecular composition of compounds that are bound to hydrogen in solutes. To remove hydrogen in water molecules, before analyses, streamwater sub-samples were completely freeze-dried (Labconco Freezone 2.5; Kansas City, Missouri, USA). The solid residues were then transferred to a $5 \mathrm{~mm}$ NMR tube and redissolved in deuterium oxide. ${ }^{1} \mathrm{H}$-NMR spectra were acquired on a two-channel Agilent Propulse $500 \mathrm{MHz}$ spectrometer (Agilent Technologies Inc., Santa Clara, California, USA), using presaturation and PURGE (Presaturation Utilizing Relaxation Gradients and Echoes) water suppression techniques with 1024 scans, $2.6 \mathrm{~s}$ acquisition time, and $20 \mathrm{~s}$ relaxation delay (d1). Spectra were processed using MNova (Mestrelab Research, Santiago de Compostela, Spain). For each ${ }^{1} \mathrm{H}$-NMR spectrum, we integrated the total signal within each of the five regions (Hertkorn et al. 2013, Santos et al. 2016), as shown in Fig. 2: aliphatic $\left({ }^{\delta} \mathrm{H} \sim 0.0\right.$ to $1.9 \mathrm{ppm})$, functionalized aliphatic $\left({ }^{\delta} \mathrm{H} \sim 1.9\right.$ to $\left.3.1 \mathrm{ppm}\right)$, oxygenated $\left({ }^{\delta} \mathrm{H} \sim 3.1\right.$ to $\left.4.3 \mathrm{ppm}\right)$, unsaturated $\left({ }^{\delta} \mathrm{H} \sim 5.3\right.$ to $7.0 \mathrm{ppm}$ ), and aromatic functional groups $\left({ }^{\delta} \mathrm{H} \sim 7.0\right.$ to $10 \mathrm{ppm})$. We expressed the total signal within each region as percentage of the total NMR signal across all five regions. We also used the aromatic:oxygenated (Arom:Oxy) ratios to evaluate whether burning increased the proportion of aromatics compared to polysaccharides in streamwater.

\section{Statistical analysis}

We examined the effects of fire severity and time since fire using linear (LMM) and generalized linear (GLMM) mixed-effects models using the package lme 4 in $R$ (Bates et al. 2015). Response variables DOC, DON, TDN, sodium cation $\left(\mathrm{Na}^{+}\right), \mathrm{Ca}^{2+}$, sulfate anions $\left(\mathrm{SO}_{4}{ }^{2-}\right)$, $\mathrm{Mg}^{2+}$, phosphate anion $\left(\mathrm{PO}_{4}{ }^{3-}\right), \mathrm{K}^{+}$, chloride anion $\left(\mathrm{Cl}^{-}\right)$, $\mathrm{NO}_{3}{ }^{-}$, and $\mathrm{NH}_{4}{ }^{+}$; as well as aromatic, unsaturated, oxygenated, functionalized aliphatic, and aliphatic functional groups; Arom:Oxy ratio; $\mathrm{SUVA}_{254}$; and $\mathrm{E}_{2}$ : $\mathrm{E}_{3}$ were analyzed separately as a function of fire severity (low versus 


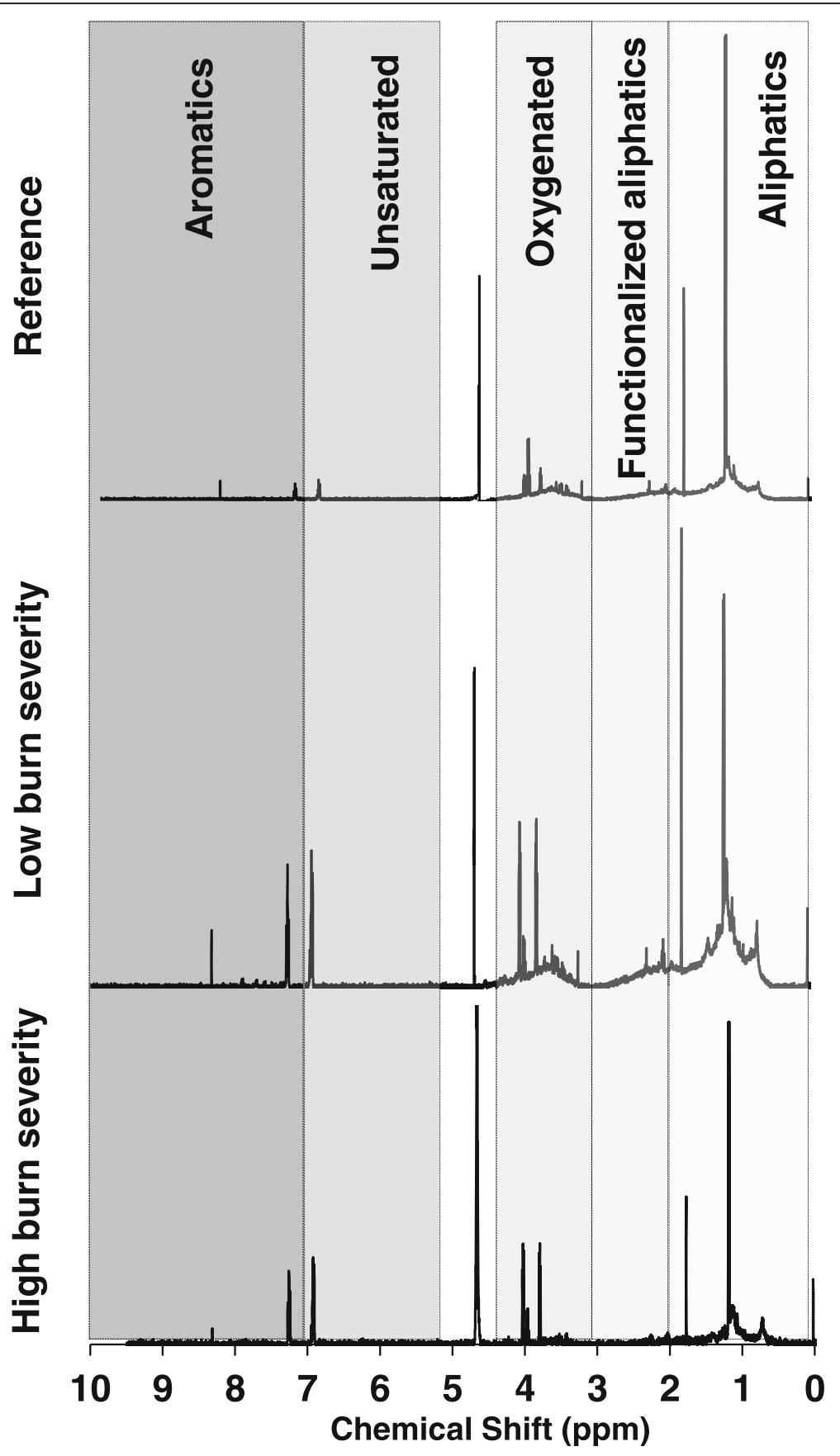

Fig. 2 Liquid-state ${ }^{1} \mathrm{H}$-NMR spectra of dissolved organic matter (DOM) representative of the reference stream, low-severity fire, and high-severity fire sites in Yosemite National Park, California, USA, with the following major functional groups assigned for DOM components (shades of gray): aromatic, unsaturated, oxygenated, functionalized aliphatic, and aliphatic structures. The water region is not included in the integration: ${ }^{\delta} \mathrm{H} \sim 4.3$ to $5.3 \mathrm{ppm}$. Sites were sampled between 1 and 13 years after the last fire

high), time since fire, and the interaction term fire severity $\times$ time since fire. To evaluate the distribution of the data, we used the Individual Distribution Identification tool in Minitab 18 Statistical Software (Minitab, Inc., State College, Pennsylvania, USA). DON, TDN, $\mathrm{Na}^{+}$, and $\mathrm{Ca}^{2+}$ fitted to a normal distribution. We used Johnson transformation to fit $\mathrm{SO}_{4}{ }^{2-}, \mathrm{Mg}^{2+}$, aromatics, unsaturated, and aliphatics, Arom:Oxy, SUVA 254 , and $\mathrm{E}_{2}: \mathrm{E}_{3}$ to a normal distribution. We used the gaussian distribution for DOC and gamma distribution for $\mathrm{PO}_{4}{ }^{3-}$, $\mathrm{K}^{+}, \mathrm{Cl}^{-}, \mathrm{NO}_{3}{ }^{-}$, and $\mathrm{NH}_{4}^{+}$; thus we used GLMM models to analyze these response variables. In GLMMs, we included fire severity and time since fire as fixed effects, and reach (to account for variability in site-level 
characteristics shown in Table 1) and collection date as random effects. For LMMs, we used the MuMIn package (https://cran.r-project.org/web/packages/MuMIn/ MuMIn.pdf) to describe the amount of the variance $\left(R^{2}\right)$ explained by the fixed effects alone (marginal, $\mathrm{R}_{\mathrm{m}}{ }^{2}$ ) and the fixed and random effects combined (conditional, $\mathrm{R}_{\mathrm{c}}^{2}$ ) (Nakagawa and Schielzeth 2013). Owing to the relatively small sample size, we were unable to include site characteristics (e.g., geomorphology, aspect, etc.) into the models as fixed effects. However, we visually evaluated patterns of aspect and bed morphology across low- and high-severity reaches via box plots (Additional files 1, 2, 3 , and 4). Because the stream reach was our main experimental unit of replication, having only one reference reach precluded its inclusion in linear models as an unburned "treatment." However, because we had multiple sampling locations and periods per reach for both reference as well as low- and high-severity fire reaches, we visually evaluated the relationships between reference and treatment responses (Table 2; Figs. 3 and 4; Additional files $1,2,3$, and 4). We determined significance at $\alpha=0.05$

Table 2 Solute concentrations and DOM molecular composition of the reference (Chilnualna) streamwater in Yosemite National Park, California, USA. Streamwater was sampled from the reference site $>100$ years after the last fire. Values shown are means \pm (standard error)

\begin{tabular}{|c|c|}
\hline Streamwater chemistry & Reference stream \\
\hline Solutes & $N=8$ \\
\hline $\mathrm{DOC}\left(\mathrm{mg} \mathrm{L}^{-1}\right)$ & $2.14(0.43)$ \\
\hline $\mathrm{DON}\left(\mathrm{mg} \mathrm{L}^{-1}\right)$ & $0.078(0.008)$ \\
\hline TDN $\left(\mathrm{mg} \mathrm{L}^{-1}\right)$ & $0.12(0.02)$ \\
\hline $\mathrm{NO}_{3}^{-}\left(\mathrm{mg} \mathrm{L}^{-1}\right)$ & $0.028(0.010)$ \\
\hline $\mathrm{NH}_{4}^{+}\left(\mu \mathrm{L}^{-1}\right)$ & $12.13(2.88)$ \\
\hline $\mathrm{Ca}^{2+}\left(\mathrm{mg} \mathrm{L}^{-1}\right)$ & $2.41(0.23)$ \\
\hline $\mathrm{Cl}^{-}\left(\mathrm{mg} \mathrm{L}^{-1}\right)$ & $3.69(0.08)$ \\
\hline $\mathrm{Na}^{+}\left(\mathrm{mg} \mathrm{L}^{-1}\right)$ & $2.84(0.14)$ \\
\hline $\mathrm{K}^{+}\left(\mathrm{mg} \mathrm{L}^{-1}\right)$ & $0.30(0.03)$ \\
\hline $\mathrm{Mg}^{2+}\left(\mathrm{mg} \mathrm{L}^{-1}\right)$ & $0.26(0.03)$ \\
\hline $\mathrm{SO}_{4}^{2+}\left(\mathrm{mg} \mathrm{L}^{-1}\right)$ & $0.10(0.01)$ \\
\hline $\mathrm{PO}_{4}^{3-}\left(\mu \mathrm{L}^{-1}\right)$ & $1.32(0.43)$ \\
\hline DOM composition & $N=4$ \\
\hline $\mathrm{SUVA}_{254}\left(\mathrm{mg} \mathrm{Cl} \mathrm{L}^{-1} \mathrm{~m}^{-1}\right)$ & $4.29(0.66)$ \\
\hline$E_{2}: E_{3}$ & $5.19(0.53)$ \\
\hline Arom:Oxy ratio & $0.04(0.01)$ \\
\hline Aromatic (\%) & $0.71(0.23)$ \\
\hline Unsaturated (\%) & $0.57(0.18)$ \\
\hline Oxygenated (\%) & $21.20(1.73)$ \\
\hline Functionalized aliphatics (\%) & $13.08(0.29)$ \\
\hline Aliphatics (\%) & $64.43(1.43)$ \\
\hline
\end{tabular}

for all analyses. All statistical analyses were conducted using Minitab 18 and R version 3.4.0 (R Development Core Team; http://www.R-project.org/).

\section{Results}

Differences in streamwater solute concentrations between burned streams and the reference stream

Visual assessment of stream solute concentrations in the reference stream (Table 2, Fig. 3) showed that streams flowing through riparian zones that burned with high severity exhibited elevated $\mathrm{Ca}^{2+}, \mathrm{Na}^{+}, \mathrm{K}^{+}$, and $\mathrm{PO}_{4}{ }^{3-}$ concentrations (Fig. 3a, b, d, and l). A similar trend was observed for these solutes in streams of low-severity fire. Overall, DOC (Fig. 3f), TDN (Fig. 3g), DON (Fig. 3i), and $\mathrm{NH}_{4}^{+}$(Fig. $3 \mathrm{~m}$ ) concentrations associated with fire severity levels were lower than those associated with the reference stream. We observed similar trends when visually evaluating these relationships based on aspect (orientation of the slope) and stream channel morphology (see also Additional files 1 and 3). For example, $\mathrm{Ca}^{2+}, \mathrm{Na}^{+}, \mathrm{K}^{+}$, and $\mathrm{PO}_{4}{ }^{3-}$ concentrations were lower in west aspect (reference stream) than in other slope classes (burned streams; Additional file 1a, b, d, and l). We also observed higher concentrations of $\mathrm{Ca}^{2+}$ and $\mathrm{K}^{+}$in pool-riffle burned streams relative to pool-riffle reference stream (Additional file $3 \mathrm{a}$ and $\mathrm{d}$ ), while $\mathrm{NH}_{4}{ }^{+}$exhibited lower concentrations in pool-riffle burned streams relative to pool-riffle reference stream (Additional file 3m).

\section{Effects of fire severity and time since fire on streamwater solute concentrations}

LMMs and GLMMs (Table 3 and Fig. 3) indicated that fire severity was related to decreased DOC $(P=0.0006)$ and DON $(P=0.026)$ concentrations. Time since fire was associated with decreased DON $(P<0.0001)$ and TDN $(P=0.032)$ concentrations and increased $\mathrm{Cl}^{-}$concentrations $(P=0.036)$ (Table 3$)$. Interactions between fire severity and time since fire were significant for DOC $(P=0.004)$ and DON $(P=0.036)$ concentrations (Table 3; Fig. $3 \mathrm{f}$ and i; Additional file $5 \mathrm{a}$ and $\mathrm{b}$ ). For high-severity fire, DOC and DON concentrations decreased with time since fire, whereas in low-severity fire, DOC concentrations increased and DON concentrations slightly decreased with time since fire. For many models, site was also an important factor when considering solute responses to fire, as suggested by the amount of variation explained $\left(\mathrm{R}_{\mathrm{c}}{ }^{2}\right)$ when random effects (reach and collection date) were included (Table 3). Random effects (Additional file 6) indicated that variability in site-level characteristics such as channel morphology and aspect played a role in solute responses (Additional files $1,2,3,4$, and 7 ). For example, $\mathrm{R}_{\mathrm{c}}{ }^{2}$ values were approximately twice as large as $\mathrm{R}_{\mathrm{m}}{ }^{2}$ values for $\mathrm{DON}$ 

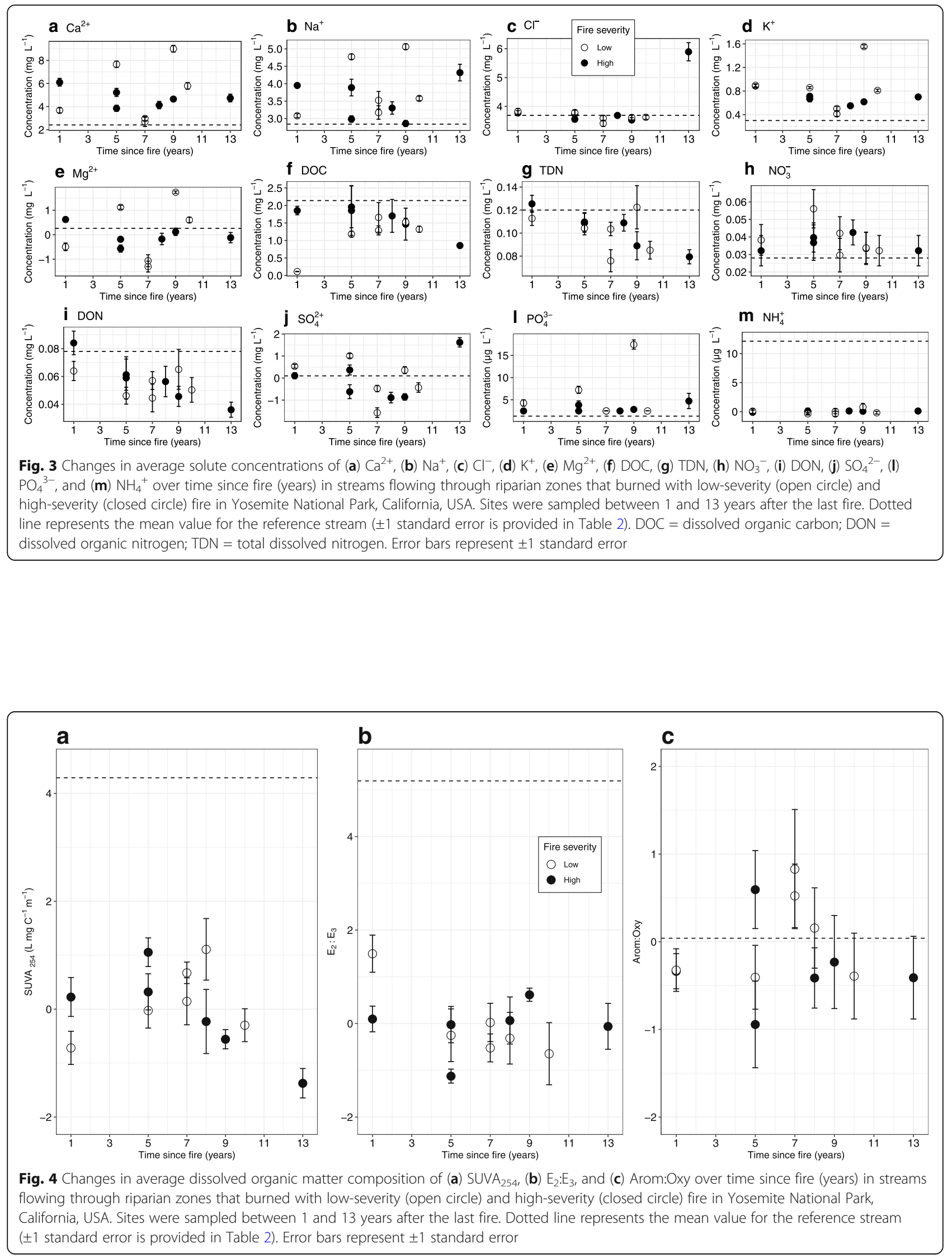
Table 3 Results from linear (LMM) and generalized linear (GLMM) mixed-effects models with fixed effects (fire severity, time since fire, fire severity $\times$ time since fire) and random effects (reach and collection date, not shown) for streamwater chemistry in burned watersheds of Yosemite National Park, California, USA. Streamwater was sampled from the sites between 1 and 13 years after the fire. Marginal $\left(R_{m}{ }^{2}\right)$ and conditional $\left(R_{c}{ }_{c}^{2}\right)$ coefficients of determination are shown for variation explained by fixed effects alone, and by both fixed and conditional effects, respectively. N/A means that $\mathrm{R}^{2}$ and denominator degrees of freedom (ddf) values are not available for GLMMs, and thus for DOC, $\mathrm{NO}_{3}{ }^{-}, \mathrm{NH}_{4}{ }^{+}, \mathrm{K}^{+}, \mathrm{Cl}^{-}$, and $\mathrm{PO}_{4}{ }^{3-}$. Bolded $\boldsymbol{P}$ values indicate a significant effect $(P<0.05)$. F. aliphatics = functionalized aliphatics

\begin{tabular}{|c|c|c|c|c|c|c|c|c|c|c|c|c|c|c|c|}
\hline & Sample & Fire se & erity & & & Time sir & ce fire & & & Fire seve & rity $\times$ ti & he since & & $\mathrm{R}^{2}$ & \\
\hline & & $\overline{\beta_{1}}$ & $F$ & ddf & P & $\overline{\beta_{1}}$ & $F$ & ddf & P & $\overline{\beta_{1}}$ & $F$ & ddf & $P$ & $\overline{R_{m}^{2}}$ & $\mathrm{R}_{c}{ }^{2}$ \\
\hline DOC & 94 & -2.02 & 4.78 & N/A & 0.0006 & -0.06 & 9.64 & N/A & 0.143 & 0.23 & 11.00 & $\mathrm{~N} / \mathrm{A}$ & 0.004 & $\mathrm{~N} / \mathrm{A}$ & $\mathrm{N} / \mathrm{A}$ \\
\hline DON & 90 & -0.03 & 5.14 & 79.23 & 0.026 & -0.004 & 9.03 & 79.18 & $<0.0001$ & 0.003 & 4.56 & 79.21 & 0.036 & 0.14 & 0.31 \\
\hline TDN & 94 & -0.02 & 1.07 & 7.75 & 0.332 & -0.004 & 5.18 & 7.71 & 0.032 & 0.002 & 0.89 & 7.66 & 0.375 & 0.13 & 0.29 \\
\hline $\mathrm{Na}^{+}$ & 94 & -0.16 & 0.02 & 8.01 & 0.879 & 0.01 & 0.51 & 8.01 & 0.888 & 0.07 & 0.28 & 8.00 & 0.608 & 0.71 & 0.82 \\
\hline $\mathrm{Ca}^{2+}$ & 94 & -1.90 & 0.51 & 8.00 & 0.494 & -0.10 & 0.24 & 8.00 & 0.673 & 0.37 & 1.05 & 8.00 & 0.335 & 0.09 & 0.90 \\
\hline $\mathrm{SO}_{4}{ }^{2+}$ & 94 & 1.30 & 1.06 & 7.99 & 0.333 & 0.08 & 0.04 & 7.99 & 0.453 & -2.20 & 1.38 & 7.99 & 0.274 & 0.08 & 0.90 \\
\hline $\mathrm{Mg}^{2+}$ & 94 & -0.87 & 0.48 & 8.00 & 0.507 & -0.03 & 0.27 & 8.00 & 0.749 & 0.16 & 0.86 & 8.00 & 0.381 & 0.07 & 0.92 \\
\hline $\mathrm{Cl}^{-}$ & 94 & 0.19 & 5.25 & N/A & 0.313 & 0.03 & 8.74 & N/A & 0.036 & -0.04 & 11.57 & N/A & 0.105 & N/A & N/A \\
\hline $\mathrm{NO}_{3}^{-}$ & 94 & 0.52 & 0.21 & N/A & 0.294 & -0.01 & 0.96 & N/A & 0.862 & -0.06 & 0.95 & $\mathrm{~N} / \mathrm{A}$ & 0.331 & $\mathrm{~N} / \mathrm{A}$ & N/A \\
\hline $\mathrm{NH}_{4}^{+}$ & 94 & -0.09 & 0.05 & N/A & 0.842 & 0.01 & 0.38 & N/A & 0.755 & 0.02 & 0.11 & N/A & 0.722 & N/A & N/A \\
\hline $\mathrm{K}^{+}$ & 94 & 0.12 & 1.33 & N/A & 0.883 & 0.03 & 1.76 & N/A & 0.680 & 0.01 & 0.05 & N/A & 0.922 & N/A & N/A \\
\hline $\mathrm{PO}_{4}{ }^{3-}$ & 94 & 0.56 & 3.21 & N/A & 0.504 & 0.03 & 0.38 & N/A & 0.677 & -0.02 & 0.11 & $\mathrm{~N} / \mathrm{A}$ & 0.841 & $\mathrm{~N} / \mathrm{A}$ & N/A \\
\hline SUVA $_{254}$ & 57 & -1.39 & 3.49 & 9.14 & 0.094 & -0.14 & 0.09 & 10.77 & 0.039 & 0.25 & 5.67 & 8.80 & 0.042 & 0.18 & 0.49 \\
\hline$E_{2}: E_{3}$ & 57 & 1.62 & 6.52 & 9.13 & 0.031 & 0.02 & 5.39 & 11.93 & 0.671 & -0.25 & 8.05 & 8.63 & 0.020 & 0.18 & 0.44 \\
\hline Arom:Oxy & 57 & 0.04 & 0.00 & 9.83 & 0.957 & -0.01 & 0.11 & 12.73 & 0.864 & 0.05 & 0.28 & 9.30 & 0.608 & 0.04 & 0.24 \\
\hline Aromatic & 57 & -0.27 & 0.13 & 9.63 & 0.722 & -0.03 & 0.01 & 12.39 & 0.599 & 0.07 & 0.52 & 9.12 & 0.490 & 0.21 & 0.27 \\
\hline Unsaturated & 57 & -0.48 & 0.68 & 9.87 & 0.430 & -0.03 & 0.00 & 12.28 & 0.505 & 0.06 & 0.56 & 9.41 & 0.472 & 0.01 & 0.44 \\
\hline Oxygenated & 57 & -4.03 & 1.00 & 10.98 & 0.338 & -0.25 & 0.00 & 15.48 & 0.477 & 0.48 & 0.72 & 10.21 & 0.415 & 0.019 & 0.024 \\
\hline F. aliphatics & 57 & 1.40 & 0.16 & 53.00 & 0.694 & 0.10 & 0.16 & 53.00 & 0.749 & -0.39 & 0.64 & 53.00 & 0.426 & 0.021 & 0.021 \\
\hline Aliphatics & 57 & 0.74 & 1.35 & 10.33 & 0.272 & 0.04 & 0.00 & 14.59 & 0.487 & -0.07 & 0.66 & 9.63 & 0.435 & 0.03 & 0.14 \\
\hline
\end{tabular}

and TDN (Table 3). Visual assessments of solute concentrations showed that the north aspect exhibited the highest concentrations of $\mathrm{Ca}^{2+}, \mathrm{K}^{+}$, and $\mathrm{Mg}^{2+}$ (Additional file 1a, d, and e). For both $\mathrm{Ca}^{2+}, \mathrm{Na}^{+}, \mathrm{K}^{+}$, $\mathrm{PO}_{4}{ }^{3-}$, the lowest concentrations were in the west aspect (Additional file $1 \mathrm{a}, \mathrm{b}, \mathrm{d}$, and $\mathrm{l}$ ), which corresponds to the aspect of the reference reach. The north-northwest aspect exhibited the highest concentrations of $\mathrm{Cl}^{-}$and $\mathrm{SO}_{4}{ }^{2+}$ (Additional file $1 \mathrm{c}$ and $\mathrm{j}$ ).

\section{Differences in streamwater DOM composition between burned streams and the reference stream}

Visual evaluation of DOM composition showed that $\mathrm{SUVA}_{254}$ (a measure of aromaticity in DOM) and $\mathrm{E}_{2}: \mathrm{E}_{3}$ (measure of DOM average molecular size) were lower for burned streams than for the reference stream (Table 2; Fig. 4a and b). In general, Arom:Oxy rations (Fig. 4c) were lower for high-severity burned streams than for the reference stream, with the exception of one high-severity burned stream. The strongest resonance in ${ }^{1} \mathrm{H}$-NMR spectra across all streams was in the aliphatic region, contributing over $60 \%$ of the proton signals from streamwater DOM (Table 2; Figs. 2, 5a and b).

\section{Effects of fire severity and time since fire on $\mathrm{SUVA}_{254}$, $E_{2}: E_{3}$ ratio, and DOM functional groups}

Time since fire alone was related to decreased $\mathrm{SUVA}_{254}$ $(P=0.039)$, whereas fire severity was associated with increased $\mathrm{E}_{2}: \mathrm{E}_{3}(P=0.031$; Table 3). The interaction fire severity $\times$ time since fire was significant for $\mathrm{SUVA}_{254}$ $(P=0.042)$ and $\mathrm{E}_{2}: \mathrm{E}_{3}$ ratios $(P=0.020$; Table 3; Fig. 4a and b; Additional file 5). For low-severity fires, SUVA $_{254}$ increased and $E_{2}: E_{3}$ ratios decreased with time since fire, whereas for high-severity fires, SUVA $_{254}$ decreased and $E_{2}: E_{3}$ ratios slightly increased with time since fire. Neither fire severity nor time since fire was a significant predictor of the relative distribution of DOM functional groups (Table 3). Visual assessment of DOM composition showed that the east aspect had higher proportion of both unsaturated and 


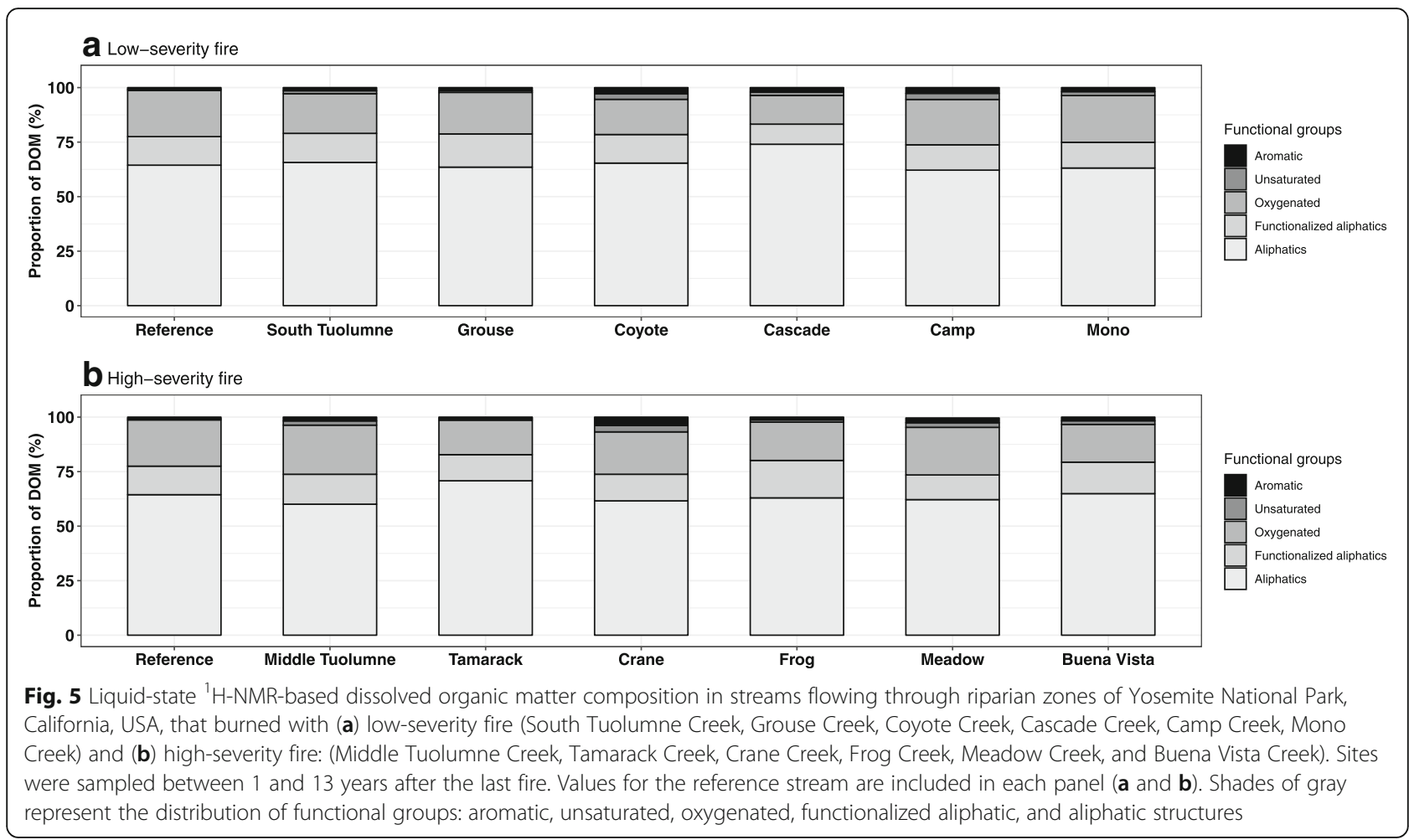

aromatics structures and Arom:Oxy ratios relative to the south aspect (Additional file $2 \mathrm{~d}$, e, and $\mathrm{f}$ ). In burned streams, $\mathrm{SUVA}_{254}$ was higher in the east than in the north-northwest aspect (Additional file 2g). There were no apparent differences in DOM composition between pool-riffle and step-pool stream channel morphology (Additional file 4).

\section{Discussion}

\section{The influence of fire}

The observed low concentrations of DOC, DON, TDN, and $\mathrm{NH}_{4}{ }^{+}$in burned streams compared with the reference stream are consistent with other studies that examined these responses within a decade after wildfire disturbance (Betts and Jones 2009). We offer two explanations for these trends. First, our results likely reflect the removal of $\mathrm{C}$ and nitrogen $(\mathrm{N})$ from surface soils by fire and runoff, which resulted in lower export of groundwater $\mathrm{C}$ and $\mathrm{N}$ from burned sites relative to unburned sites. Second, it is also possible that the lower $\mathrm{C}$ concentrations relative to reference streams resulted from the removal of aboveground vegetation by fire, decreasing evapotranspiration, and increasing baseflow. In contrast to our results for DOC, DON, TDN, and $\mathrm{NH}_{4}{ }^{+}$, the concentrations of other solutes $\left(\mathrm{Ca}^{2+}, \mathrm{Na}^{+}, \mathrm{K}^{+}\right.$, and $\mathrm{PO}_{4}{ }^{3-}$ ) increased relative to the reference stream, similar to results reported for other regions (Chorover et al. 1994, Williams and Melack 1997, Stephens et al. 2004, Bêche et al. 2005, Engle et al. 2008). Greater concentrations of these solutes relative to the reference stream are attributed to the dissolution of these ions from post-burn ashes (inorganic residues) in deep soil or deposited into stream sediments (Ranalli 2004). However, we acknowledge that using a single reference stream may limit the interpretation of our results drawn from this comparison by constraining local, site-level variability. For instance, our reference site represented pool-riffle bed morphology and west-facing slope, and thus limited our understanding of how variability in bed morphology (e.g., step-pool) and aspect may interact with fire to influence solutes. Nonetheless, using the unburned stream as a counterpoint to our burned streams provided complementary information and additional context that was helpful in interpreting our results.

\section{The interaction between fire severity and time since fire}

Our results indicated that declines in DOC and DON concentrations, aromaticity (expressed as decreased SUVA $_{254}$ ), and mean molecular weight DOM (expressed as increased $E_{2}: E_{3}$ ratios) with time since fire were associated with high-severity fires. The thermal degradation of OM typically decreases $\mathrm{C}$ stocks in the forest floor and soil C concentrations (Nave et al. 2011), therefore limiting the supply of soil DOM. As such, an increase in fire severity can lead to decreased $\mathrm{C}$ and $\mathrm{N}$ concentrations and stocks in surface soils (Homann et al. 2011), decreasing the amount of $\mathrm{C}$ and $\mathrm{N}$ that is vertically transported to lower soil depths and ultimately exported 
to streams. In studies conducted two to three years following a fire in the Sierra Nevada, high-severity fires were reported to decrease total C stocks in organic horizons relative to unburned treatments (Maestrini et al. 2017, Adkins et al. 2019). During high-severity fires, increases in soil heating can also decrease mineral soil C concentrations (Almendros et al. 2003, Araya et al. 2017) and lead to low molecular weight DOM (Norwood et al. 2013, Santos et al. 2016) transported from soils to streams. Our results suggest that an increase in fire severity decreased $\mathrm{C}$ and $\mathrm{N}$ concentrations and molecular size of DOM over time under baseflow conditions, likely due to the thermal degradation of topsoil OM. Increases in hydrophobicity in post-fire soils (DeBano 2000, Doerr et al. 2000, González-Pérez et al. 2004) inhibits water infiltration during the wet season, increasing postprecipitation runoff and the transport of OM from soils to streams. In this investigation, however, runoff was not the process feeding DOM into the study streams, as our sampling occurred during the dry (summer and fall) seasons. As such, our results reflect processes occurring at baseflow. Under such conditions, terrigenous DOM is primarily transported to streams via subsurface flow (Johnson and Reynolds Jr. 1977, Inamdar et al. 2011, Lee et al. 2018).

Our results for aromaticity suggest that the export of aromatic compounds, possibly from $\mathrm{PyC}$, from soils to streams under baseflow conditions responds differently to different fire severities over time. Soil heating and the thermal degradation of $\mathrm{OM}$ by fire increase the amount of particulate and soluble PyC in surface soils (Miesel et al. 2015, Santos et al. 2016), a portion of which can move to lower soil depths via leaching (Hockaday et al. 2006, 2007; Santos et al. 2017) and has been documented in major rivers around the globe (Jaffé et al. 2013). We attribute the decrease in post-fire PyC export from soils to streams in high-severity fire to the greater losses of PyC remaining in soil during the first years after fire. The first storms after fire typically lead to greater post-precipitation erosion and runoff (Spigel and Robichaud 2007, Scott et al. 2009), thus greater removal of $\mathrm{OM}$ (including $\mathrm{PyC}$ ) and its concomitant transport from soils to streams. In contrast to our results for high-severity fire, aromaticity in low-severity burned streams, where conifer canopy remains intact, increased with time. Increases in aromaticity are typically associated with increases in photochemical reactions between DOC and ultraviolet light (i.e., photodegradation) and often correlate with decreases in DOM bioavailability (Balcarczyk et al. 2009, Cory et al. 2014). An increase in aromatic compounds in DOC could decrease aquatic productivity; it has been shown that bacterial production rates are not stimulated by aromatic, slow cycling compounds. Rather, rates of bacterial production are often stimulated by more labile forms of DOC (Berggren et al. 2010). Decreased aromaticity with time since fire in high-severity fires would likely decrease rates of DOC photo-mineralization to carbon dioxide $\left(\mathrm{CO}_{2}\right)$ and increase aquatic productivity, heterotrophy, and other associated metabolic processes. Understanding the coupled response and cycling of carbon and nitrogen $(\mathrm{N})$ in this landscape, however, remains unclear.

\section{The influence of time since fire}

Time since fire was associated with decreased total and organic $\mathrm{N}$ concentrations and proportions of aromatic compounds in DOC pool, but increased $\mathrm{Cl}^{-}$concentrations. These results suggest that, under baseflow conditions, these variables respond to fire for multiple years and are likely related to post-burn vegetation recovery and concurrent increases in the biological uptake of $\mathrm{N}$, a limiting nutrient in soil, and $\mathrm{Cl}^{-}$mobilization. Thus, it is possible that the supply of soil $\mathrm{N}$ that is vertically transported to lower soil depths and ultimately exported to streams over time decreased with vegetation recovery. Our results for $\mathrm{N}$ contrast to the elevated TDN concentrations reported 14 years after fire in Colorado (Rhoades et al. 2018), suggesting that other site-level processes (e.g., land cover type) might play a role in how $\mathrm{N}$ cycles in fire-affected watersheds. The underlying mechanisms leading to increased $\mathrm{Cl}^{-}$concentrations over time is unclear, but it is possibly related to changes in chemical weathering rates. Nonetheless, the magnitude of $\mathrm{N}$ and $\mathrm{Cl}^{-}$responses are likely not high enough to significantly impact freshwater ecosystems.

\section{The influence of site-level characteristics}

Site-level characteristics, when included as a random effect in the LMMs and GLMMs, emerged as playing a role in the responses of solutes to fire. Results suggest that the responses observed in this study are an integrative signal, capturing processes at the site-to-subcatchment scale. For example, we observed elevated $\mathrm{Ca}^{2+}, \mathrm{K}^{+}$, and $\mathrm{Mg}^{2+}$ in burned (but not reference) stream reaches with pool-riffle versus step-pool bed morphology (Additional file 3a, d, and e). The mechanisms behind the relationship between specific site-characteristics and streamwater chemistry are unclear, but likely associated with the role of bedrock lithology in affecting both chemical weathering rates and the geomorphic structure of the stream channel. Lower values of $\mathrm{Ca}^{2+}$ and $\mathrm{K}^{+}$at our pool-riffle and west aspect reference reach may suggest an interaction between bed morphology, aspect, and fire. The effect of site-level characteristics is consistent with previous observations that streamwater chemistry as well as DOC quantity can be impacted by landscape and catchment characteristics (Johnson et al. 1997, Clow and Sueker 2000, 
Ahearn et al. 2005, Li et al. 2013, Larouche et al. 2015, Lintern et al. 2018). For example, findings from a study conducted in Rocky Mountain National Park, Colorado, USA, revealed that topography and geology explained $80 \%$ of the variation in the concentration of many solutes in streamwater (Clow and Sueker 2000). Topography (i.e., slope and elevation), for instance, controls fire severity, hydrological flow within catchments, and the transport of sediments and solutes to streams (Certini 2005, Lintern et al. 2018). We observed that north-northwest aspect was associated with particularly high concentrations of $\mathrm{Cl}^{-}$and $\mathrm{SO}_{4}{ }^{2-}$ (Additional file $1 \mathrm{c}$ and $\mathrm{j}$ ). Thus, local catchment characteristics must be considered in predictive models when assessing the long-term effects of wildfires on streamwater DOM and other solutes. This approach would improve predictions of streamwater chemistry's vulnerability to projected increases in wildfire frequency and severity, and the areal size in the Sierra Nevada (Miller et al. 2009, Miller and Safford 2012, Kitzberger et al. 2017). Further research is needed to better understand the importance of landscape characteristics in controlling the transport of terrigenous DOM and other solutes to fluvial networks.

\section{Aliphatic: the dominant structure in streamwater DOM}

Aliphatic structures (i.e., lipids, fatty acids, and amino acids) dominated streamwater DOM composition across the fire-impacted catchments, consistent with previous studies that analyzed the composition of DOM from freshwater systems (Repeta et al. 2002, Bianchi et al. 2004, Lam et al. 2007). Our results showed no differences in the proportion of aliphatic structures between burned and unburned streams. Additionally, neither fire severity nor time since fire were significant predictors of proportion of aliphatic structures in streamwater DOM. Taken together, these results suggest that fire does not affect processes that control the mobilization and transport of these DOM compounds from deep soils to streams. The predominance of aliphatic structures in streamwater DOM is commonly assumed to be of autochthonous origin (i.e., algae in streamwater; Degens et al. 1991); however, aliphatic compounds are also reported to dominate in deep soils, presumably derived from microbial residues (Rumpel and Kögel-Knabner 2011). Owing to the fact that these streams were predominately first- and second-order streams with full canopies, it is most likely that the major aliphatic structures detected in streamwater are of allochthonous origin, providing further evidence that the measured DOM was exported from deep soils (Lee et al. 2018).

\section{Conclusions}

In the western US, the amount of area burned is increasing, with fire projected to increase in frequency and severity (Miller et al. 2009, Miller and Safford 2012, Kitzberger et al. 2017). In our study, fire severity, time since fire, as well as their interaction, and variability in site-level characteristics emerged as the strongest influences on streamwater chemistry. These results suggest that multiple-year responses of streamwater chemistry to wildfires in the Sierra Nevada will depend on fire severity. Post-fire changes in streamwater chemistry could have long-term implications for aquatic organisms and the balance of energy and nutrient availability and stoichiometry (e.g., C:N) during the dry season and when internal production may be low. Changes in energy and nutrient limitation could affect metabolic processes of aquatic ecosystems (Wymore et al. 2016). Understanding how wildfire severity and time since fire will interact to affect larger ecosystems and landscape-scale processes will be key to understanding how catchments will respond to future disturbances.

\section{Additional files}

Additional file 1: Boxplots showing fire-affected streamwater solute concentrations of (a) $\mathrm{Ca}^{2+}$, (b) $\mathrm{Na}^{+}$, (c) $\mathrm{Cl}^{-}$, (d) $\mathrm{K}^{+}$, (e) $\mathrm{Mg}^{2+}$, (f) DOC, (g) TDN, (h) $\mathrm{NO}_{3}{ }^{-}$, (i) DON, (j) $\mathrm{SO}_{4}{ }^{2-}$, (l) $\mathrm{PO}_{4}{ }^{3-}$, and (m) $\mathrm{NH}_{4}{ }^{+}$across aspect classes (E, N, NNW, NW, S, SE, SW, and W) in burned watersheds of Yosemite National Park, California, USA. Sites were sampled between 1 and 13 years after the last fire. Boxplot in $\mathrm{W}$ represents the reference reach. Dark circles represent mean concentration values and the grey circle denotes mean concentration value for the reference reach (see also Table 2). Crosses (+) indicate potential outliers. (PDF $13 \mathrm{~kb}$ )

Additional file 2: Boxplots showing fire-affected streamwater dissolved organic matter composition of (a) aliphatics, (b) functionalized aliphatics, (c) oxygenated, (d) unsaturated, (e) aromatic, (f) Arom:Oxy, (g) SUVA 254 , and $(h) E_{2}: E_{3}$ across aspect classes ( $E, N, N N W, N W, S, S E, S W$, and $W$ ) in burned watersheds of Yosemite National Park, California, USA. Sites were sampled between 1 and 13 years after the last fire. Boxplot in W represents the reference reach. Dark circles represent mean concentration values and the grey circle denotes mean concentration value for the reference reach (see also in Table 2). Crosses (+) indicate potential outliers. (PDF $9 \mathrm{~kb}$ )

Additional file 3: Boxplots of fire-affected streamwater solute concentrations of (a) $\mathrm{Ca}^{2+}$, (b) $\mathrm{Na}^{+}$, (c) $\mathrm{Cl}^{-}$, (d) $\mathrm{K}^{+}$, (e) $\mathrm{Mg}^{2+}$, (f) DOC, (g) TDN, (h) $\mathrm{NO}_{3}{ }^{-}$, (i) $\mathrm{DON}$, (j) $\mathrm{SO}_{4}{ }^{2-}$, (l) $\mathrm{PO}_{4}{ }^{3-}$, and (m) $\mathrm{NH}_{4}{ }^{+}$in pool-riffle and step-pool channel morphology in Yosemite National Park, California, USA. Sites were sampled between 1 and 13 years after the last fire. Dark circles represent mean concentration values and the gray circle for pool-riffle denotes mean concentration value for the reference reach (see also Table 2). Crosses (+) indicate potential outliers. (PDF $76 \mathrm{~kb}$ )

Additional file 4: Boxplots of fire-affected streamwater dissolved organic matter composition of (a) aliphatics, (b) functionalized aliphatics, (c) oxygenated, (d) unsaturated, (e) aromatic, (f) Arom:Oxy, (g) SUVA 254 , and (h) $E_{2}: E_{3}$ in pool-riffle and step-pool channel morphology in Yosemite National Park, California, USA. Sites were sampled between 1 and 13 years after the last fire. Dark circles represent mean concentration values and the gray circle for the pool-riffle denotes mean concentration value for the reference reach (see also Table 2). Crosses (+) indicate potential outliers. (PDF 65 kb)

Additional file 5: Predicted values from mixed-effect models (GLMMs) of (a) DOC, (b) DON, (c) SUVA 254 , and (e) $E_{2}: E_{3}$ for low-severity (dashed lines) and high-severity (solid lines) fire across time since fire (years) in burned watersheds of Yosemite National Park, California, USA. Sites were sampled between 1 and 13 years after the last fire. Gray shaded areas represent 95\% confidence band. (PDF $5 \mathrm{~kb}$ ) 
Additional file 6: Caterpillar plots of the random effects for the mixed effect models (GLMMs) for streamwater solute concentrations of (a) $\mathrm{Ca}^{2+}$ (b) $\mathrm{Na}^{+}$, (c) $\mathrm{Cl}^{-}$, (d) $\mathrm{K}^{+}$, (e) $\mathrm{Mg}^{2+}$, (f) DOC, (g) TDN, (h) $\mathrm{NO}_{3}{ }^{-}$, (i) DON, (j) $\mathrm{SO}_{4}{ }^{2-}$, (l) $\mathrm{PO}_{4}{ }^{3-}$, and $(\mathrm{m}) \mathrm{NH}_{4}{ }^{+}$in burned watersheds of Yosemite National Park, California, USA. Burned watersheds are: BV = Buena Vista Creek, $\mathrm{Mo}=$ Mono Creek, $\mathrm{Cr}=$ Crane Creek, $\mathrm{Co}=$ Coyote Creek, Fr $=$ Frog Creek, Cas $=$ Cascade Creek, Me = Meadow Creek, Cam = Camp Creek, $\mathrm{Ta}=$ Tamarack Creek, $\mathrm{Gr}=$ Grouse Creek, MT = Middle Tuolumne Creek, ST = South Tuolumne Creek. Sites were sampled between 1 and 13 years after the last fire. Horizontal lines indicate $95 \%$ prediction intervals for six reaches burned at low fire severity and 6 reaches burned at high fire severity. (PDF $59 \mathrm{~kb}$ )

Additional file 7: Caterpillar plots of the random effects for the mixed-effect models (GLMMs) for streamwater dissolved organic matter composition of (a) aliphatics, (b) functionalized ali (aliphatics), (c) oxygenated, (d) unsaturated, (e) aromatic, (f) Arom:Oxy, (g) SUVA 254 , and (h) $E_{2}: E_{3}$ in burned watersheds of Yosemite National Park, California, USA. Sites were sampled between 1 and 13 years after the last fire. Horizontal lines indicate 95\% prediction intervals for six reaches burned at low fire severity and six reaches burned at high fire severity. (PDF $7 \mathrm{~kb}$ )

\section{Acknowledgments}

We thank the Water Quality Analysis Laboratory at the University of New Hampshire for assistance, and D. Rice for assistance with liquid-state NMR spectroscopy (UC Merced NMR Facility), K. van Wagtendonk for the fire severity data, and field technicians M. Hickson and M. Ledford. The authors wish to thank the three anonymous reviewers for their comments and suggestions on earlier drafts of this manuscript.

\section{Funding}

Field work was conducted under permit number YOSE-2014-SCI-0096. Funding for field work was provided by National Science Foundation (NSF) Division of Environmental Biology 1401480 awarded to S.M.P. Sullivan and B.K. Jackson, and Bureau of Land Management (14-3-01-37) awarded to S.M.P. Sullivan. F. Santos acknowledges financial support from the UC Merced Chancellor's Postdoctoral Fellowship, and A.A. Berhe acknowledges support from NSF (CAREER, EAR - 1352627). Additional funding for data analysis and manuscript preparation was provided to A.S. Wymore and W.H. McDowell by the New Hampshire Agricultural Experiment Station. This is Scientific Contribution \#2782. This work also was supported by the USDA National Institute of Food and Agriculture (McIntire-Stennis), project accession 1006760

\section{Availability of data and materials}

The datasets used or analyzed during the current study are available from the corresponding author on reasonable request.

\section{Authors' contributions}

F. Santos, A.S. Wymore, and A.A. Berhe led efforts in devising the study objectives and approach, and in writing the manuscript. S.M.P. Sullivan and B.K. Jackson established the original study site and provided the background data. B.K. Jackson collected the samples, and F. Santos and A.S. Wymore conducted the measurements. F. Santos, S.M.P. Sullivan, and A.S. Wymore analyzed the data. W.H. McDowell provided support for solute measurements, and A.A. Berhe provided support for DOM composition measurements. All authors provided input and revisions in constructing the final version of the manuscript. All authors read and approved the final manuscript.

\section{Ethics approval and consent to participate}

Not applicable.

\section{Consent for publication}

Not applicable.

\section{Competing interests}

The authors declare that they have no competing interests.

\section{Publisher's Note}

Springer Nature remains neutral with regard to jurisdictional claims in published maps and institutional affiliations.

\section{Author details}

1School of Natural Sciences, Department of Life and Environmental Sciences, University of California, 5200 North Lake Road, Merced, CA 95343, USA. ${ }^{2}$ Department of Natural Resources and the Environment, University of New Hampshire, 114 James Hall, Durham, NH 03824, USA. ${ }^{3}$ Resource Management and Science Division, Yosemite National Park, 5083 Foresta Road, El Portal, CA 95318, USA. ${ }^{4}$ The Wilma H. Schiermeier Olentangy River Wetland Research Park, School of Environment and Natural Resources, The Ohio State University, 352 West Dodridge Street, Columbus, OH 43202, USA.

Received: 9 July 2018 Accepted: 21 November 2018 Published online: 14 March 2019

\section{References}

Abiven, S., P. Hengartner, M.P. Schneider, N. Singh, and M.W. Schmidt. 2011 Pyrogenic carbon soluble fraction is larger and more aromatic in aged charcoal than in fresh charcoal. Soil Biology and Biochemistry 43: 1615-1617. https://doi.org/10.1016/j.soilbio.2011.03.027.

Abney, R., and A.A. Berhe. 2018. Pyrogenic carbon erosion: implications for stock and persistence of pyrogenic carbon in the soil system. Frontiers in Earth Science 6: 26. https://doi.org/10.3389/feart.2018.00026.

Abney, R.B., J. Sanderman, D. Johnson, M.L. Fogel, and A.A. Berhe. 2017. Postwildfire erosion in mountainous terrain leads to rapid and major redistribution of soil organic carbon. Frontiers in Earth Science 5: 99. https:// doi.org/10.3389/feart.2017.00099.

Adkins, J., J. Sanderman, and J. Miesel. 2019. Soil carbon pools and fluxes vary across a burn severity gradient three years after wildfire in Sierra Nevada mixed-conifer forest. Geoderma 333: 10-22. https://doi.org/10.1016/j. geoderma.2018.07.009.

Ahearn, D.S., R.W. Sheibley, R.A. Dahlgren, M. Anderson, J. Johnson, and K.W. Tate. 2005. Land use and land cover influence on water quality in the last freeflowing river draining the western Sierra Nevada, California. Journal of Hydrology 313: 234-247. https://doi.org/10.1016/j.jhydrol.2005.02.038.

Almendros, G., H. Knicker, and F.J. Gonzalez-Vila. 2003. Rearrangement of carbon and nitrogen forms in peat after progressive thermal oxidation as determined by solid-state 13C- and 15N-NMR spectroscopy. Organic Geochemistry 34: 1559-1568. https://doi.org/10.1016/S0146-6380(03)00152-9.

Araya, S.N., M.L. Fogel, and A.A. Berhe. 2017. Thermal alteration of soil organic matter properties: a systematic study to infer response of Sierra Nevada climosequence soils to forest fires. SOIL 3: 31-44. https://doi.org/10.5194/soil3-31-2017.

Araya, S.N., S.M. Meding, and A.A. Berhe. 2016. Thermal alteration of soil physicochemical properties: a systematic study to infer response of Sierra Nevada climosequence soils to forest fires. SOIL 2: 351-366. https://doi.org/10.5194/ soil-5192-5351-2016.

Balcarczyk, K.L., J.B. Jones, R. Jaffé, and N. Maie. 2009. Stream dissolved organic matter bioavailability and composition in watersheds underlain with discontinuous permafrost. Biogeochemistry 94: 255-270. https://doi.org/10. 1007/s10533-009-9324-x.

Bates, D., M. Mächler, B. Bolker, and S. Walker. 2015. Fitting linear mixed-effects models using Ime4. Journal of Statistical Software 67 (1): 1-48. https://doi.org/ 10.18637/jss.v067.i01.

Bêche, L.A., S.L. Stephens, and V.H. Resh. 2005. Effects of prescribed fire on a Sierra Nevada (California, USA) stream and its riparian zone. Forest Ecology and Management 218: 37-59. https://doi.org/10.1016/j.foreco.2005.06.010.

Berggren, M., H. Laudon, M. Haei, L. Ström, and M. Jansson. 2010. Efficient aquatic bacterial metabolism of dissolved low-molecular-weight compounds from terrestrial sources. The ISME Journal 4: 408. https://doi.org/10.1038/ismej.2009.120.

Betts, E.F., and J.B. Jones. 2009. Impact of wildfire on stream nutrient chemistry and ecosystem metabolism in boreal forest catchments of interior Alaska. Arctic, Antarctic, and Alpine Research 41: 407-417. https://doi.org/10.1657/ 1938-4246-41.4.407.

Bianchi, T.S., T. Filley, K. Dria, and P.G. Hatcher. 2004. Temporal variability in sources of dissolved organic carbon in the lower Mississippi River. Geochimica et Cosmochimica Acta 68: 959-967. https://doi.org/10.1016/j.gca.2003.07.011.

Certini, G. 2005. Effects of fire on properties of forest soils: a review. Oecologia 143: 1-10. https://doi.org/10.1007/s00442-004-1788-8.

Chorover, J., P.M. Vitousek, D.A. Everson, A.M. Esperanza, and D. Turner. 1994. Solution chemistry profiles of mixed-conifer forests before and after fire. Biogeochemistry 26: 115-144. https://doi.org/10.1007/BF02182882. 
Clow, D.W., and J.K. Sueker. 2000. Relations between basin characteristics and stream water chemistry in alpine/subalpine basins in Rocky Mountain National Park, Colorado. Water Resources Research 36: 49-61. https://doi.org/ 10.1029/1999WR900294.

Cory, R.M., C.P. Ward, B.C. Crump, and G.W. Kling. 2014. Sunlight controls water column processing of carbon in Arctic fresh waters. Science 345: 925-928. https://doi.org/10.1126/science.1253119.

Cotrufo, M.F., C.M. Boot, S. Kampf, P.A. Nelson, D.J. Brogan, T. Covino, M.L. Haddix, L.H. MacDonald, S. Rathburn, and S. Ryan-Bukett. 2016. Redistribution of pyrogenic carbon from hillslopes to stream corridors following a large montane wildfire. Global Biogeochemical Cycles 30: 1348-1355. https://doi. org/10.1002/2016GB005467.

Dahm, C.N., R.I. Candelaria-Ley, C.S. Reale, J.K. Reale, and D.J. Van Horn. 2015. Extreme water quality degradation following a catastrophic forest fire. Freshwater Biology 60: 2584-2599. https://doi.org/10.1111/fwb.12548.

DeBano, L.F. 2000. The role of fire and soil heating on water repellency in wildland environments: a review. Journal of Hydrology 231: 195-206. https:// doi.org/10.1016/S0022-1694(00)00194-3.

Degens, E., S. Kempe, and J. Richey. 1991. Biochemistry of major world rivers; scope 42. Chichester: Wiley.

Diemer, L.A., W.H. McDowell, A.S. Wymore, and A.S. Prokushkin. 2015. Nutrient uptake along a fire gradient in boreal streams of central Siberia. Freshwater Science 34: 1443-1456. https://doi.org/10.1086/683481.

Dittmar, T., C.E. de Rezende, M. Manecki, J. Niggemann, A.R. Coelho Ovalle, A. Stubbins, and M.C. Bernardes. 2012. Continuous flux of dissolved black carbon from a vanished tropical forest biome. Nature Geoscience 5: 618-622. https://doi.org/10.1038/ngeo1541.

Doerr, S., R. Shakesby, and R. Walsh. 2000. Soil water repellency: its causes, characteristics and hydro-geomorphological significance. Earth-Science Reviews 51: 33-65. https://doi.org/10.1016/S0012-8252(00)00011-8.

Engle, D.L., J.O. Sickman, C.M. Moore, A.M. Esperanza, J.M. Melack, and J.E. Keeley. 2008. Biogeochemical legacy of prescribed fire in a giant sequoia-mixed conifer forest: a 16-year record of watershed balances. Journal of Geophysical Research 113: G01014. https://doi.org/10.1029/2006JG000391.

Esposito, G., F. Matano, F. Molisso, G. Ruoppolo, A. Di Benedetto, and M. Sacchi. 2017. Post-fire erosion response in a watershed mantled by volcaniclastic deposits, Sarno Mountains, southern Italy. Catena 152: 227-241. https://doi. org/10.1016/j.catena.2017.01.009.

Florsheim, J.L., A. Chin, A.M. Kinoshita, and S. Nourbakhshbeidokhti. 2017. Effect of storms during drought on post-wildfire recovery of channel sediment dynamics and habitat in the southern California chaparral, USA. Earth Surface Processes and Landforms 42: 1482-1492. https://doi.org/10. 1002/esp.4117.

González-Pérez, J.A., F.J. González-Vila, G. Almendros, and H. Knicker. 2004. The effect of fire on soil organic matter-a review. Environment International 30: 855-870. https://doi.org/10.1016/j.envint.2004.02.003.

Güereña, D.T., J. Lehmann, T. Walter, A. Enders, H. Neufeldt, H. Odiwour, H. Biwott, J. Recha, K. Shepherd, and E. Barrios. 2015. Terrestrial pyrogenic carbon export to fluvial ecosystems: lessons learned from the White Nile watershed of East Africa. Global Biogeochemical Cycles 29: 1911-1928. https://doi.org/10. 1002/2015GB005095.

Helms, J.R., A. Stubbins, J.D. Ritchie, E.C. Minor, D.J. Kieber, and K. Mopper. 2008. Absorption spectral slopes and slope ratios as indicators of molecular weight, source, and photobleaching of chromophoric dissolved organic matter. Limnology and Oceanography 53: 955-969. https://doi.org/10.4319/lo.2008.53.3.0955.

Hertkorn, N., M. Harir, B. Koch, B. Michalke, and P. Schmitt-Kopplin. 2013. High-field NMR spectroscopy and FTICR mass spectrometry: powerful discovery tools for the molecular level characterization of marine dissolved organic matter. Biogeosciences 10: 1583-1624. https://doi.org/10.5194/bg-10-1583-2013.

Hockaday, W.C., A.M. Grannas, S. Kim, and P.G. Hatcher. 2006. Direct molecular evidence for the degradation and mobility of black carbon in soils from ultrahigh-resolution mass spectral analysis of dissolved organic matter from a fire-impacted forest soil. Organic Geochemistry 37: 501-510. https://doi.org/10. 1016/j.orggeochem.2005.11.003.

Hockaday, W.C., A.M. Grannas, S. Kim, and P.G. Hatcher. 2007. The transformation and mobility of charcoal in a fire-impacted watershed. Geochimica et Cosmochimica Acta 71: 3432-3445. https://doi.org/10.1016/j.gca.2007.02.023.

Homann, P.S., B.T. Bormann, R.L. Darbyshire, and B.A. Morrissette. 2011. Forest soil carbon and nitrogen losses associated with wildfire and prescribed fire. Soil Science Society of America Journal 75: 1926-1934. https://doi.org/10.2136/ sssaj2010-0429.
Inamdar, S., S. Singh, S. Dutta, D. Levia, M. Mitchell, D. Scott, H. Bais, and P. McHale. 2011. Fluorescence characteristics and sources of dissolved organic matter for stream water during storm events in a forested mid-Atlantic watershed. Journal of Geophysical Research 116: G03043. https://doi.org/10. 1029/2011JG001735.

Jackson, B.K., and S.M.P. Sullivan. 2009. Influence of wildfire severity on riparian plant community heterogeneity in an Idaho, USA wilderness. Forest Ecology and Management 259: 24-32. https://doi.org/10.1016/j.foreco.2009.09.036.

Jackson, B.K., and S.M.P. Sullivan. 2015. Responses of riparian tetragnathid spiders to wildfire in forested ecosystems of the California mediterranean climate region, USA. Freshwater Science 34: 1542-1557. https://doi.org/10.1086/683682.

Jaffé, R., Y. Ding, J. Niggemann, A.V. Vähätalo, A. Stubbins, R.G. Spencer, J. Campbell, and T. Dittmar. 2013. Global charcoal mobilization from soils via dissolution and riverine transport to the oceans. Science 340: 345-347. https://doi.org/10.1126/science.1231476.

Johnson, A.H., and R.C. Reynolds Jr. 1977. Chemical character of headwater streams in Vermont and New Hampshire. Water Resources Research 13: 469473. https://doi.org/10.1029/WR013i002p00469.

Johnson, L., C. Richards, G. Host, and J. Arthur. 1997. Landscape influences on water chemistry in Midwestern stream ecosystems. Freshwater Biology 37: 193-208. https://doi.org/10.1046/j.1365-2427.1997.d01-539.x.

Keeler-Wolf, T., P. Moore, E. Reyes, J. Menke, D. Johnson, and D. Karavidas. 2012. Yosemite National Park vegetation classification and mapping project report. USDI National Park Service Natural Resource Technical Report NPS/YOSE/ NRTR-2012/598, National Forest Service, Fort Collins, Colorado.

Keeley, J.E. 2009. Fire intensity, fire severity and burn severity: a brief review and suggested usage. International Journal of Wildland Fire 18: 116-126. https:// doi.org/10.1071/WF07049.

Kitzberger, T., D.A. Falk, A.L. Westerling, and T.W. Swetnam. 2017. Direct and indirect climate controls predict heterogeneous early-mid 21st century wildfire burned area across western and boreal North America. PLOS ONE 12: e0188486. https://doi.org/10.1371/journal.pone.0188486.

Knicker, H. 2007. How does fire affect the nature and stability of soil organic nitrogen and carbon? A review. Biogeochemistry 85: 91-118. https://doi.org/ 10.1007/s10533-007-9104-4.

Lam, B., A. Baer, M. Alaee, B. Lefebvre, A. Moser, A. Williams, and A.J. Simpson. 2007. Major structural components in freshwater dissolved organic matter. Environmental Science \& Technology 41: 8240-8247. https://doi.org/10.1021/ es0713072.

Larouche, J.R., B.W. Abbott, W.B. Bowden, and J.B. Jones. 2015. The role of watershed characteristics, permafrost thaw, and wildfire on dissolved organic carbon biodegradability and water chemistry in Arctic headwater streams. Biogeosciences 12: 4221-4233. https://doi.org/10.5194/bg-12-4221-2015.

Lee, B.S., K. Lajtha, J.A. Jones, and A.E. White. 2018. Fluorescent DOC characteristics are related to streamflow and pasture cover in streams of a mixed landscape. Biogeochemistry 140: 317-340. https://doi.org/10.1007/ s10533-018-0494-2.

Li, S., X. Xia, X. Tan, and Q. Zhang. 2013. Effects of catchment and riparian landscape setting on water chemistry and seasonal evolution of water quality in the upper Han River basin, China. PLOS ONE 8: e53163. https://doi. org/10.1371/journal.pone.0053163.

Lintern, A., J.A. Webb, D. Ryu, S. Liu, U. Bende-Michl, D. Waters, P. Leahy, P. Wilson, and A.W. Western. 2018. Key factors influencing differences in stream water quality across space. Wiley Interdisciplinary Reviews-Water 5: e1260. https://doi.org/10.1002/wat2.1260.

Lydersen, J.M., M.P. North, and B.M. Collins. 2014. Severity of an uncharacteristically large wildfire, the Rim Fire, in forests with relatively restored frequent fire regimes. Forest Ecology and Management 328: 326-334. https://doi.org/10.1016/j.foreco.2014.06.005.

Maestrini, B., E.C. Alvey, M.D. Hurteau, H. Safford, and J.R. Miesel. 2017. Fire severity alters the distribution of pyrogenic carbon stocks across ecosystem pools in a Californian mixed-conifer forest. Journal of Geophysical Research-Biogeosciences 122: 2338-2355. https://doi.org/10. 1002/2017JG003832.

Malison, R.L., and C.V. Baxter. 2010. The fire pulse: wildfire stimulates flux of aquatic prey to terrestrial habitats driving increases in riparian consumers. Canadian Journal of Fisheries and Aquatic Sciences 67: 570-579. https://doi. org/10.1139/F10-006.

Masiello, C., and P. Louchouarn. 2013. Fire in the ocean. Science 340: 287-288. https://doi.org/10.1126/science.1237688. 
Mast, M.A., and D.W. Clow. 2008. Effects of 2003 wildfires on stream chemistry in Glacier National Park, Montana. Hydrological Processes 22: 5013-5023. https:// doi.org/10.1002/hyp.7121.

Mast, M.A., S.F. Murphy, D.W. Clow, C.A. Penn, and G.A. Sexstone. 2016. Waterquality response to a high-elevation wildfire in the Colorado Front Range. Hydrological Processes 30: 1811-1823. https://doi.org/10.1002/hyp.10755.

McCune, B., and D. Keon. 2002. Equations for potential annual direct incident radiation and heat load. Journal of Vegetation Science 13: 603-606. https:// doi.org/10.1111/j.1654-1103.2002.tb02087.x.

Miesel, J.R., W.C. Hockaday, R.K. Kolka, and P.A. Townsend. 2015. Soil organic matter composition and quality across fire severity gradients in coniferous and deciduous forests of the southern boreal region. Journal of Geophysical Research-Biogeosciences 120: 1124-1141. https://doi.org/10.1002/ 2015JG002959.

Miller, J.D., and H. Safford. 2012. Trends in wildfire severity: 1984 to 2010 in the Sierra Nevada, Modoc Plateau, and southern Cascades, California, USA. Fire Ecology 8: 41-57. https://doi.org/10.4996/fireecology.0803041.

Miller, J.D., H.D. Safford, M. Crimmins, and A.E. Thode. 2009. Quantitative evidence for increasing forest fire severity in the Sierra Nevada and southern Cascade mountains, California and Nevada, USA. Ecosystems 12: 16-32. https://doi.org/ 10.1007/s10021-008-9201-9.

Montgomery, D.R., and J.M. Buffington. 1997. Channel-reach morphology in mountain drainage basins. Geological Society of America Bulletin 109: 596-611. https://doi.org/10.1130/0016-7606(1997)109\%3C0596:CRMIMD\%3E2.3.CO;2.

Moody, J.A., R.A. Shakesby, P.R. Robichaud, S.H. Cannon, and D.A. Martin. 2013. Current research issues related to post-wildfire runoff and erosion processes. Earth-Science Reviews 122: 10-37. https://doi.org/10.1016/j.earscirev.2013.03.004.

Myers-Pigg, A.N., P. Louchouarn, R.M. Amon, A. Prokushkin, K. Pierce, and A. Rubtsov. 2015. Labile pyrogenic dissolved organic carbon in major Siberian Arctic rivers: implications for wildfire-stream metabolic linkages. Geophysical Research Letters 42: 377-385. https://doi.org/10.1002/2014GL062762.

Nakagawa, S., and H. Schielzeth. 2013. A general and simple method for obtaining R2 from generalized linear mixed-effects models. Methods in Ecology and Evolution 4: 133-142 https://doi.org/10.1111/j.2041-210x.2012. 00261.x.

Näthe, K., D.F. Levia, M. Steffens, and B. Michalzik. 2017. Solid-state 13C NMR characterization of surface fire effects on the composition of organic matter in both soil and soil solution from a coniferous forest. Geoderma 305: 394406. https://doi.org/10.1016/j.geoderma.2017.06.030.

Nave, L.E., E.D. Vance, C.W. Swanston, and P.S. Curtis. 2011. Fire effects on temperate forest soil C and N storage. Ecological Applications 21: 1189-1201. https://doi.org/10.1890/10-0660.1.

Norwood, M.J., P. Louchouarn, L.-J. Kuo, and O.R. Harvey. 2013. Characterization and biodegradation of water-soluble biomarkers and organic carbon extracted from low temperature chars. Organic Geochemistry 56: 111-119. https://doi.org/10.1016/j.orggeochem.2012.12.008.

Parham, L.M., A.S. Prokushkin, O.S. Pokrovsky, S.V. Titov, E. Grekova, L.S. Shirokova, and W.H. McDowell. 2013. Permafrost and fire as regulators of stream chemistry in basins of the Central Siberian Plateau. Biogeochemistry 116: 55 68. https://doi.org/10.1007/s10533-013-9922-5.

Ramchunder, S.J., L.E. Brown, and J. Holden. 2013. Rotational vegetation burning effects on peatland stream ecosystems. Journal of Applied Ecology 50: 636648. https://doi.org/10.1111/1365-2664.12082

Ranalli, A.J. 2004. A summary of the scientific literature on the effects of fire on the concentration of nutrients in surface waters. Reston: US Geological Survey Open File Report 2004-1296. https://doi.org/10.3133/ofr20041296.

Reilly, M.J., C.J. Dunn, G.W. Meigs, T.A. Spies, R.E. Kennedy, J.D. Bailey, and K. Briggs. 2017. Contemporary patterns of fire extent and severity in forests of the Pacific Northwest, USA (1985-2010). Ecosphere 8 (3): e01695. https://doi. org/10.1002/ecs2.1695.

Repeta, D.J., T.M. Quan, L.I. Aluwihare, and A. Accardi. 2002. Chemical characterization of high molecular weight dissolved organic matter in fresh and marine waters. Geochimica et Cosmochimica Acta 66: 955-962. https:// doi.org/10.1016/S0016-7037(01)00830-4.

Rhoades, C.C., A.T. Chow, T.P. Covino, T.S. Fegel, D.N. Pierson, and A.E. Rhea. 2018. The legacy of a severe wildfire on stream nitrogen and carbon in headwater catchments. Ecosystems: 1-15. https://doi.org/10.1007/s10021-018-0293-6.

Rhoades, C.C., D. Entwistle, and D. Butler. 2011. The influence of wildfire extent and severity on streamwater chemistry, sediment and temperature following the Hayman Fire, Colorado. International Journal of Wildland Fire 20: 430-442. https://doi.org/10.1071/WF09086.
Rumpel, C., and I. Kögel-Knabner. 2011. Deep soil organic matter-a key but poorly understood component of terrestrial C cycle. Plant and Soil 338: $143-$ 158. https://doi.org/10.1007/s11104-010-0391-5.

Santín, C., S.H. Doerr, C.M. Preston, and G. González-Rodríquez. 2015. Pyrogenic organic matter production from wildfires: a missing sink in the global carbon cycle. Global Change Biology 21: 1621-1633. https://doi.org/10.1111/gcb.12800.

Santos, F., D. Russell, and A.A. Berhe. 2016. Thermal alteration of water extractable organic matter in climosequence soils from the Sierra Nevada, California. Journal of Geophysical Research-Biogeosciences 121: 2877-2885. https://doi. org/10.1002/2016JG003597.

Santos, F., S. Wagner, D. Rothstein, R. Jaffe, and J.R. Miesel. 2017. Impact of a historical fire event on pyrogenic carbon stocks and dissolved pyrogenic carbon in spodosols in northern Michigan. Frontiers in Earth Science 5: 80 https://doi.org/10.3389/feart.2017.00080.

Sawyer, J.O., T. Keeler-Wolf, and J. Evens. 2009. A manual of California vegetation. Second edition. Sacramento: California Native Plant Society.

Scott, D.F., M.P. Curran, P.R. Robichaud, and J.W. Wagenbrenner. 2009. Soil erosion after forest fire. In Fire effects on soils and restoration strategies, ed. A. Cerda and P.R. Robichaud, 177-195. Enfield: Science Publishers. https://doi. org/10.1201/9781439843338-c6.

Smith, H.G., G.J. Sheridan, P.N. Lane, P. Nyman, and S. Haydon. 2011. Wildfire effects on water quality in forest catchments: a review with implications for water supply. Journal of Hydrology 396: 170-192. https://doi.org/10.1016/j. jhydrol.2010.10.043.

Spigel, K.M., and P.R. Robichaud. 2007. First-year post-fire erosion rates in Bitterroot National Forest, Montana. Hydrological Processes 21: 998-1005. https://doi.org/10.1002/hyp.6295.

Stephens, S.L., T. Meixner, M. Poth, B. McGurk, and D. Payne. 2004. Prescribed fire, soils, and stream water chemistry in a watershed in the Lake Tahoe Basin, California. International Journal of Wildland Fire 13: 27-35. https://doi.org/10. 1071/WF03002

Strahler, A.N. 1957. Quantitative analysis of watershed geomorphology. Eos Transactions American Geophysical Union 38: 913-920. https://doi.org/10. 1029/TR038i006p00913.

U.S. EPA. 1993. "Method 350.1: Nitrogen, Ammonia (Colorimetric, Automated Phenate)," Revision 2.0. Cincinnati, $\mathrm{OH}$

Wagner, S., K.M. Cawley, F.L. Rosario-Ortiz, and R. Jaffé. 2015. In-stream sources and links between particulate and dissolved black carbon following a wildfire. Biogeochemistry 124: 145-161. https://doi.org/10.1007/s10533-015-0088-1.

Weishaar, J.L., G.R. Aiken, B.A. Bergamaschi, M.S. Fram, R. Fujii, and K. Mopper. 2003. Evaluation of specific ultraviolet absorbance as an indicator of the chemical composition and reactivity of dissolved organic carbon. Environmental Science \& Technology 37: 4702-4708. https://doi.org/10.1021/es030360x.

Williams, M.R., and J.M. Melack. 1997. Effects of prescribed burning and drought on the solute chemistry of mixed-conifer forest streams of the Sierra Nevada, California. Biogeochemistry 39: 225-253. https://doi.org/10.1023/A:1005858219050.

Wymore, A.S., A.A. Coble, B. Rodríguez-Cardona, and W.H. McDowell. 2016. Nitrate uptake across biomes and the influence of elemental stoichiometry: a new look at LINX II. Global Biogeochemical Cycles 30: 1183-1191. https://doi.org/10. 1002/2016GB005468.

\section{Submit your manuscript to a SpringerOpen ${ }^{\circ}$ journal and benefit from:}

- Convenient online submission

- Rigorous peer review

- Open access: articles freely available online

- High visibility within the field

- Retaining the copyright to your article

Submit your next manuscript at $>$ springeropen.com 